\title{
Economics
}

The Open-Access, Open-Assessment E-Journal

Vol. 12, 2018-41 | June 25, 2018 | http://dx.doi.org/10.5018/economics-ejournal.ja.2018-41

\section{The impact of Basel III on money creation: a synthetic theoretical analysis}

\author{
Wanting Xiong and Yougui Wang
}

\begin{abstract}
Inspired by the extensive criticisms against the textbook fractional reserve theory, this paper revisits the mechanics of money creation process and complements the traditional focus on the reserve requirement by elaborating on the roles of three prudential regulations proposed in the Basel III accord. In particular, the authors consider such conditions where the financial markets are imperfect and suffer from various frictions that the commercial bank cannot readily modulate their liquidity and capital buffers, especially at an aggregate level or within a short period. Meanwhile, as a result of maturity mismatch and fundamental uncertainty, the credit and money creation activities inevitably add to the liquidity and insolvency risks faced by the bank. Under the assumptions that the levels of bank reserves, capital and government bonds are exogenously given, and that the concerned prudential regulations are always binding, the authors examine the determinants of the broad money aggregate and the money multiplier. Specifically, they find that 1) the money multiplier under Basel III is not constant but a decreasing function of the monetary base; 2) the determinants of the bank's money creation capacity are regulation specific; 3) when multiple regulations are imposed simultaneously, the effective binding regulation and the corresponding money multiplier will vary across different economic states and bank balance sheet conditions.
\end{abstract}

JEL E51 G28 G18 E60

Keywords Money creation; Basel III; liquidity coverage ratio; capital adequacy ratio; leverage ratio; money multiplier

\section{Authors}

Wanting Xiong, School of Systems Science, Beijing Normal University, Beijing, China Yougui Wang, School of Systems Science, Beijing Normal University, Beijing, China, ygwang@bnu.edu.cn

Citation Wanting Xiong and Yougui Wang (2018). The impact of Basel III on money creation: a synthetic theoretical analysis. Economics: The Open-Access, OpenAssessment E-Journal, 12 (2018-41): 1-34. http://dx.doi.org/10.5018/economicsejournal.ja.2018-41 


\section{Introduction}

Since the financial crisis in September 2008, central banks have greatly expanded the scope of its tools to stimulate economies by cutting interest rates to the zero lower bound and taking on unconventional measures such as "quantitative easing" (QE). In consequence, there has been commensurate increase in the monetary base together with a tripling or quadrupling of the size of central bank balance sheets. However, these actions have had much less impact on bank lending and the broad money aggregate. In particular, the money multiplier, which was reasonably stable under normal conditions, experienced unprecedented plummeting to less than half of its pre-crisis level (see Figure 1 for the empirical movements of the M0 stock, the M2 stock and the money multiplier in the U.S.). ${ }^{1}$

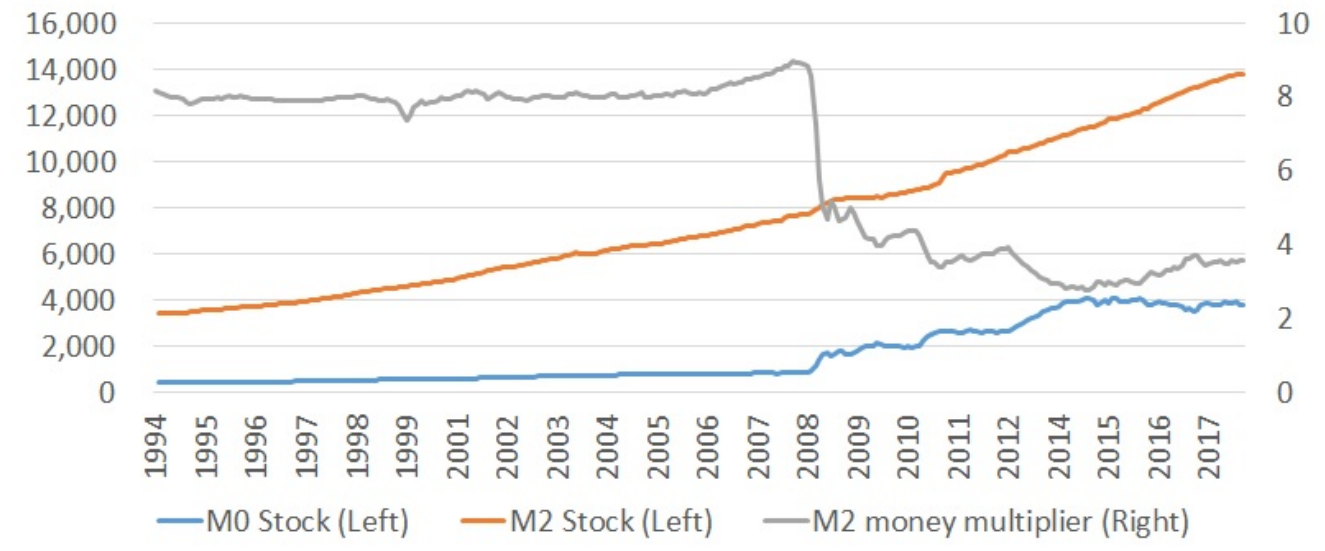

Figure 1: The M0 stock (US dollar), the M2 stock (US dollar) and the M2 money multiplier in the U.S. from 1994 to 2017. Data source: https://fred.stlouisfed.org.

Such collapse of the money multiplier and sluggish response of bank lending to expansionary monetary policy stand in stark contrast to the descriptions of the traditional fractional reserve theory of banking (FRT) and the related bank lending channel of monetary transmission. According to the FRT, the lending behavior of an individual commercial bank is constrained by the amount of deposits and the reserve requirement to which it is subject. Since the amount of required reserves is a fraction of the total deposits, the broad money supply by the banking system as whole is a multiplier of the monetary base. This money multiplier is expressed as the inverse of the required reserve ratio in its simplest form and is often considered to be constant. Therefore, a bank lending channel exists wherein monetary shocks to the level of bank reserves are "multiplied up" to greater changes in deposits and deposits, insofar as they constitute the supply of loanable funds, affect bank lending.

The wide gap between the reality and the FRT suggests a serious need to reassess the role of banks in money creation (Werner, 2014; McLeay et al., 2014; Ábel et al., 2016; Botos, 2016). Inherent in the traditional view of banking are two assumptions: 1) the central bank controls the money supply by varying the supply of reserves and the required reserve ratio, and 2) the

1 Relevant discussions and more data illustrations for other countries can be found in Goodhart (2015); Honda (2004); Disyatat (2011). 
availability of reservable deposits is a binding constraint on commercial bank lending. Regarding the first point, it is argued by many (Ryan-Collins et al., 2012; Goodhart, 2010; Komáromi, 2007) that most central banks have shifted their policy target from the quantity control of reserves to the price control of short-term interest rates. In order to achieve the target interest rate and facilitate the smooth functioning of the interbank payment system, reserves are supplied by the central bank non-discretionarily to meet the demand of commercial bank under normal conditions. Thus, the amount of reserves are mainly determined by the structural characteristics of the payment system. This renders the reserve requirement policy a less important aspect in the central bank governing framework (Bernanke, 2007; McLeay et al., 2014). In fact, several countries, including Canada, United Kingdom, Australia, and New Zealand, have no reserve requirement at all. For countries that do retain this policy, it is often exercised with a time lag (e.g. at least 17 days in the U.S.) (Fullwiler, 2012).

With respect to the second point, there are a number of reasons to be skeptical about the causal relationship from reservable deposits to bank lending. For one, with increasingly easy access to non-deposit or nonreservable-deposit fundings, for example, due to the development of wholesale markets (Carpenter and Demiralp, 2012), the growth in loan securitization (Loutskina and Strahan, 2009), and the globalization of banking (Puri et al., 2011), it is very unlikely that banks will reduce lending as they cannot replace the shortfall of reservable deposits. More importantly, the implicit assumption that banks are simply financial intermediaries that lend out the deposits saved with them is essentially misplaced. Instead, banks are different from other financial institutions in that they create deposits, which are used as the common method of payment, out of nothing through lending (Moore, 1988; Palley, 1994; Disyatat, 2011; Keen, 2011; McLeay et al., 2014; Werner, 2014). In this sense, loans drive deposits rather than the other way around.

In other words, it can thus be implied that due to recent financial innovation and policy change, the reserve requirement is playing a less important role in constraining the money creation process. Nevertheless, in contrast to the attenuation of the reserve requirement as a regulatory constraint for commercial banks, prudential regulations have become much more stringent and complex following the recent financial crisis, which constitutes a non-negligible impact on bank activities (McLeay et al., 2014). In addition, although there can be no direct link between the drop in the money multiplier in the aftermath of the 2008 financial crisis and the regulatory changes proposed in the Basel III accord in 2010, the implementation of these new prudential instruments may well have a reductive impact on or even substitute the conventional role of the reserve requirement as the binding constraint in the money creation process. Building on the previous rethinkings and criticisms of the FRT, this paper aims to explore why and how prudential regulations could have a constraining effect on the ability of the commercial bank to create money, which therefore provides a new insight into the classical money creation process. In particular, we study the influences of the Basel III accord, one of the most influential international frameworks of prudential regulation proposed by the Basel Committee on Banking Supervision in the aftermath of the 2008 financial crisis (Basel Committee on Banking Supervision, 2011). Compared to its previous versions, the new Basel accord strengthens the regulatory requirement on the bank's minimum capital position, both by narrowing the definition of eligible capital and by requesting a significant rise of the Capital Adequacy Ratio (CAR). Additionally, the Basel III accord marks the transition of the 
banking supervision framework to a multi-polar regime, with the additional introduction of new prudential regulations that focus on different financial risks, such as the Liquidity Coverage Ratio (LCR) and the Leverage Ratio (LR) requirement. While the traditional CAR regulation mainly addresses the insolvency risk resulting from loan default or other asset depreciation, the LCR regulation aims to improve the liquidity or risk profile of the bank during stressful times, and the LR regulation tackles with the risks in modeling or estimating the overall risk exposure and serves as a non-discretionary limit on the expansion of bank balance sheets.

Although a profusion of efforts have been made in evaluating and predicting the macroeconomic impact of the Basel III accord, this paper attempts to add to this literature in several aspects. To begin with, we examine the influences of Basel III regulations on the liability side (money) of the commercial bank's balance sheet, so as to complement the more extensive discussions about its effects on the bank's asset side (credit). On the one hand, it is well demonstrated by existing literature that the bank's credit supply will be negatively affected by the tightening of capital related prudential requirements, either in terms of decreased growth rate or increased price, especially in the short term.$^{2}$ On the other hand, much less attention is paid to the changes in the bank's liability side, i.e. the money supply, as the result of the variations in the regulatory constraints faced by the commercial bank. To the best of our knowledge, a few exceptions can be found in Honda (2004); Panagopoulos (2010); Li et al. (2017). Specifically, Honda (2004) extends the textbook money creation model to incorporate the impact of capital based regulations and demonstrates that the transmission of monetary shocks via the asset (the credit channel) and the commercial bank's liability side (the money channel) are two different mechanisms. Panagopoulos (2010) investigates empirically the influence of Basel II type CAR regulation on the Greek banking system and concludes that its money creation process can be favorably explained by the Post Keynesian Structuralism theory of endogenous money. Li et al. (2017) examines the role of the latest LCR regulation in money creation and finds that such regulatory constraint might lead to a reduction in the money multiplier.

Furthermore, we contribute to the understandings of the interactions among different prudential requirements by taking into account the simultaneous imposition of multiple regulatory instruments. While the benefits of such multi-polar regulatory regime in addressing different types of risks and frictions are straightforward, there is considerable uncertainty about the collective consequences of multiple prudential regulations when being imposed at the same time(Haldane, 2015). Therefore, in response to the call by Haldane (2015) for more efforts in examining the complexity of the multi-polar regulatory framework, this paper considers three prudential regulations in the Basel III accord, including the CAR, LCR and LR regulations. More specifically, we examine the role of these regulations in the money creation process by answering three questions. The first question is, what determines the broad money supply and the corresponding money multiplier when each concerned regulation is taking effect alone? Second, when multiple regulations are imposed at the same time, which of them is the binding constraint that dictates the ability of the bank to create money? Last but not least, as most prudential regulations are ratio controls of the items on bank balance sheets, it is also vital to know how the effective binding regulation and the corresponding

2 See VanHoose (2007); Peek and Rosengren (2010); Martynova (2015) for reviews of related studies. 
money multiplier vary with changes in the structure of bank balance sheet in different economic conditions.

In order to answer these questions, we model the money creation process and focus on the behaviors of the commercial bank in a simplified stock-flow consistent framework that respects both the accounting principle and the law of motion between stock and flow variables. Similar as the FRT, we take the monetary base and the concerned regulations as exogenously given, while the level of loans and deposits are endogenously determined in the money creation process. In addition, the bank's holdings of capital and high quality liquid assets are also assumed to be exogenous variables. This assumption accounts for economic conditions where the relevant financial markets are imperfect and suffer from various frictions, which renders it impossible or prohibitively expensive for the bank to increase its capital or liquidity buffer, especially within a short time period. In addition, we abstract from the rest of the economy by assuming that the loan demand is higher than the loan supply and that the interest rate of lending is always profitable for the bank. Compared with works that attempt to assess or predict the more general macroeconomic impact of Basel III in terms of social welfare or aggregate output (e.g. Slovik and Cournède (2011); Allen et al. (2012); Angelini et al. (2015); Miles et al. (2013); Yan et al. (2012); Quinaz and Curto (2016)), we study a shorter logic chain that involves much fewer intertwined macroeconomic causalities $^{3}$ and correspondingly organize our analysis in a paired-down theoretical framework that intends to give qualitative rather than quantitative conclusions about the constraining effects of prudential regulations on money creation. The merits of this approach are that the reasoning process is straightforward and easy to follow, and that the theoretical implications of new Basel regulations in the money creation process can be directly compared with those of the classical reserve requirement.

Based on this theoretical framework, we obtain the corresponding expressions for the money supply and money multiplier for each individual regulation, and examine their relations with corresponding determinants. We find that 1) when the banking system is constrained by any of the three prudential regulations, the money multiplier responds negatively to the increase of the monetary base, which is different from the constant money multiplier when the bank is only constrained by the reserve requirement; 2) raising the monetary base may not boost the broad money supply when the LR regulation acts as the binding constraint; 3 ) the determinants of the money supply and the money multiplier are specific to the binding regulation by which the bank is constrained. In the case where multiple regulations take effect simultaneously, we find that the effective binding regulation that casts the most rigid constraint on the bank lending and money creation can be different when there are changes in the underlying economic environment and the bank's balance sheet structure. Consequently, the corresponding money multiplier and its determinants will also vary. We argue that this result calls for special attention from the policy makers because the same policy may have distinct consequences in different scenarios.

The remainder of the paper is structured as follows. Section 2 elaborates on the role of commercial banks in money creation and the mechanism through which Basel III regulations affect

3 For instance, we do not consider the interplay between banks and the rest of the economy, including the impact of the former's credit and money supply on the latter's aggregate demand, nor the changes in the latter's investment in bank liabilities. 
bank lending behaviors and consequently the broad money supply. Section 3 presents the model and the corresponding equilibrium conditions. Section 4 first presents the standalone impact of each individual regulation on money creation (Section 4.1) and further demonstrates the collective influence when all three regulations are simultaneously imposed (Section 4.2). Section 5 presents the conclusions.

\section{Money creation, commercial bank balance sheet and prudential regulations}

"In the modern economy, most money takes the form of bank deposits. But how those bank deposits are created is often misunderstood: Whenever a bank makes a loan, it simultaneously creates a matching deposit in the borrower's bank account, thereby creating new money."

—McLeay et al. (2014), Bank of England, Quarterly Bulletin 2014 Q1

Commercial banks play a central role in money creation. When a bank makes a loan, the most common means is to directly credit the borrower's deposit account, which thereby expands both sides of the bank's balance sheet. When loans are repaid, the amount of deposits decreases. In this sense, bank lending can never be constrained by a lack of debt financing sources as deposits are its own product. Instead, the limit on credit creation comes from the portfolio management of banks to stay liquid, solvent and profitable, for both voluntary and mandatory reasons. To understand this, let us take a detailed look at the bank's business model and the mechanism through which the reserve requirement and prudential regulations take effect.

The most fundamental means by which a bank generates profit is to earn the interest spread between its assets (e.g. loans) and liabilities (e.g. deposits). This thus motivates the bank to make more loans that expands the balance sheet. On the other hand, such a business model also entails various risks for the bank, which stem from the asymmetric properties of its assets and liabilities. Deposits should be paid on demand while loans are due only on specific dates. This inherent property of maturity mismatch is the source for the liquidity risk. Also, the potential loan default or other types of asset depreciation, when coincides with inadequate net worth, gives rise to the insolvency risk. Usually, the liquidity risk is managed by maintaining a safety buffer of high liquid assets and guaranteeing the access to stable funding sources during stressed market conditions, whilst the solvency risk is managed by a sufficiently large capital buffer and deliberate risk management strategy (see Figure 2 for illustration).

From this perspective, the reserve requirement can be viewed as a liquidity regulation acting to guarantee the adequacy of liquid assets that are required in the events of interbank payments and deposits withdrawal. However, the constraining effect of this requirement on bank credit creation have much attenuated in the past decades for several reasons. For instance, as a result of the implementation of expansionary monetary policy in economies struck by the crisis, the banking systems in these economies are usually flooded with reserves that renders the actual reserve ratio much higher than the minimum regulatory standard. Moreover, even before the crisis, thanks to the development of the wholesale funding market, it is easy for banks to meet the reserve requirement by substituting reservable deposits or raising contingent funds. 


\section{(a) Example for liquidity risk}

Asset Liability

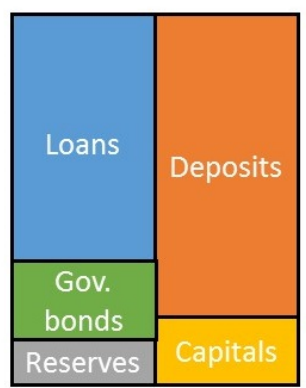

Large amount of "flighty" deposit relative to liquid assets such as reserves
Asset Liability

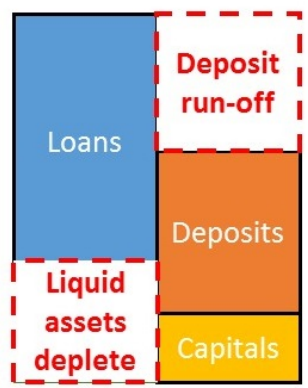

Bank replies on its liquid asset to pay for deposit withdrawal. Since loans are not due to be paid soon, bank defaults when its liquid assets are depleted.

(b) Example for solvency risk

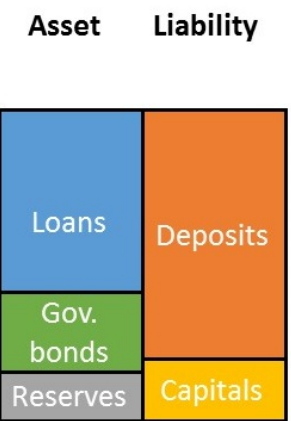

High-risk loans with thin capital base
Asset Liability

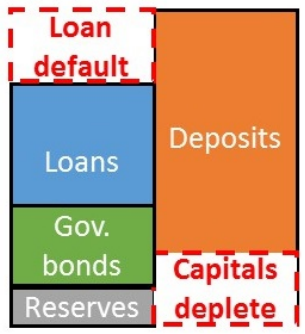

Capitals absorb the loss from loan default until depleted. Bank becomes insolvent when its liabilities are larger than its assets.

Figure 2: Illustration for liquidity risk (a) and solvency risk (b). Figure adapted from Farag et al. (2013).

In addition, driven by the desire for profit, banks are often prone to underestimate the liquidity and solvency risks which gradually build up during economic booms when the expectations for profitability are collectively high and the short-term fundings are stable and easily obtainable. Also, the explicit or implicit government guarantees under stressed conditions including deposit 
insurance, bail-outs and last-resort lending, also give rise to the problem of "moral hazard" whereby banks take on excessive risks and maintain lower levels of capital and liquid assets than they would otherwise. This sort of development is argued to be the reason underlying the excessive expansion of credit and the accumulation of financial instability in the lead up to the financial crisis (McLeay et al., 2014; Farag et al., 2013; Fullwiler, 2012).

Therefore, in order to guard against this intrinsic destabilizing nature of the financial sector, prudential regulations are indispensable for constraining bank behaviors in a more targeted fashion (Horváth et al., 2014; Jakab and Kumhof, 2015; Li et al., 2017; Farag et al., 2013; Dermine, 2013). Consequently, since the introduction of capital requirements in the Basel I accord, the impact of bank capital and capital regulations on bank lending has been a heated topic for researchers. Theoretically, several mechanisms have been proposed to explain how lending is affected by the capital position of the bank and relevant capital requirements: 1) the threshold effect of binding capital constraint, where capital-constrained banks become more responsive to contractionary monetary policy and less motivated by expansionary policy (Van den Heuvel, 2002; Furfine, 2001; Honda, 2004); 2) the bank profit effect, where monetary policy tightening results in reduced profit that constitutes lower bank equity and thus leads to a persistent decline in lending (Van den Heuvel, 2006; Chami and Cosimano, 2010); 3) the risk premium effect, where the level of bank capital acts as the signal of the bank's health for its creditors and thereby affects the risk premium of the bank in raising external funds (Disyatat, 2011). With respect to empirical evidence, the constraining effects of bank capital and capital regulations on bank lending have been generally confirmed. On the one hand, it is well documented by studies across different countries and time periods ${ }^{4}$ that the capital position of individual bank is an important factor in determining their response to monetary shocks. On the other hand, more recent works (Francis and Osborne, 2009, 2012; Bridges et al., 2014; Aiyar et al., 2016; Mésonnier and Monks, 2014; Noss and Toffano, 2014) focus on the impact of varying capital requirement and estimate a short-term reduction of bank lending ranging from $1.2 \%$ to $4.5 \%$ due to a $1 \%$ increase in capital requirement.

Notwithstanding the extensive discussions on the impact of capital requirement on the bank lending channel, few investigations have been made regarding the constraining effect of other prudential regulations on the money creation process such as the newly proposed LCR regulation, not to mention the more complicated case where multiple prudential regulations are simultaneously imposed. $^{5}$

In the Basel III accord framework, the liquidity risk is addressed by the LCR regulation while the solvency risk is attended by the CAR and LR regulations. Next, we explain the meanings of these regulations and how they limit bank lending and the money supply.

Liquidity Coverage Ratio The Basel III accord requires a bank to hold sufficient high-quality liquid assets (HQLA) to cover its total net cash outflow (NCOF) over 30 days under stressed

\footnotetext{
4 For the U.S., see Peek and Rosengren (1995a,b); Kishan and Opiela (2000, 2006); for EU countries, see Gambacorta and Mistrulli (2004); Altunbaş et al. (2002); Gambacorta and Marques-Ibanez (2011); Puri et al. (2011); for India, see Nachane et al. (2006); Albertazzi and Marchetti (2010); for Japan, see Peek and Rosengren (1997); for Spain, see Jiménez and Ongena (2012); for Malaysia, see Abdul Karim et al. (2011).

5 See Li et al. (2017); Xiong et al. (2018) for exception.
} 
conditions. Mathematically, the liquidity coverage ratio is defined as

$$
L C R=\frac{H Q L A}{N C O F} .
$$

The minimum liquidity coverage ratio was initially set at $60 \%$ in 2015 and should rise in equal annual increment to reach $100 \%$ on 1 January 2019.

According to the Basel III regulations, high quality liquid assets are assets that have low default risk and easy convertibility into cash at little or no loss of value. Meanwhile, the total net cash outflow is defined as the total expected cash outflow $(O F)$ minus the total expected cash inflow $(I F)$ up to an aggregate cap of $75 \%$ of the total expected cash outflow in the specified stress scenario for the subsequent 30 calendar days, i.e.

$$
N C O F=O F-\min \{I F, 0.75 O F\} .
$$

The $75 \%$ cap of total expected cash outflow is introduced to prevent banks from relying solely on anticipated inflow to meet their liquidity requirement so that they must maintain a minimum amount of stock of HQLA equal to $25 \%$ of the total cash outflow(Basel Committee on Banking Supervision, 2013).

Risk-based capital adequacy ratio To strengthen the capital framework of the banking sector, the Basel III accord raises the minimum requirement of bank capital in relation to the risk-weighted assets $(R W A)$ and introduces two additional capital buffers: a mandatory "capital conservation buffer" and a "discretionary counter-cyclical buffer", allowing national regulators to require additional capital buffer during periods of high credit growth. The risk-based capital adequacy ratio is usually defined based on the Tier-1 core capital (CET1), which is bank capital with the highest quality classification, over the risk-weighted assets, i.e.

$$
C A R=\frac{C E T 1}{R W A} .
$$

Compared to Basel II, the minimum requirement of CET 1 over RWA is raised from $2 \%$ to $4.5 \%$, while the mandatory "capital conservation buffer" requires $2.5 \%$ and the "discretionary countercyclical buffer" ranges from $0 \%$ to $2.5 \%$. Therefore, the actual minimum requirement of CAR facing banks is $7 \%$ in all periods and even up to $9.5 \%$ under certain conditions.

Leverage Ratio The leverage ratio regulation is a non-risk-based capital requirement. It is calculated by dividing the amount of Tier 1 capital by the average total consolidated assets(TA), including the exposures of all assets and non-balance sheet items. In other words, the leverage ratio is defined as

$$
L R=\frac{C E T 1}{T A} .
$$

The leverage ratio is introduced as a backstop to the risk-based capital adequacy ratio with the aim of constraining excess leverage in the banking system and providing an extra layer of protection against model risk and measurement error. Basel III requires the banks to maintain a leverage ratio in excess of 3\%. A higher minimum leverage ratio is requested by the U.S. Federal Reserve for eight systemically important financial institution banks and their insured bank holding companies. 


\section{Before Lending}

(a)

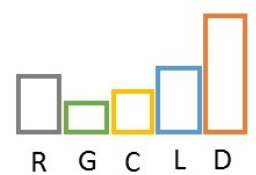

(b)

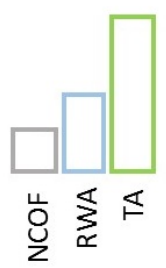

(c)

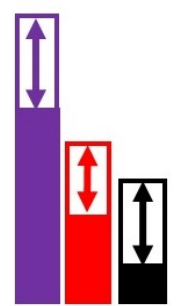

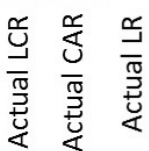

\section{After Lending}
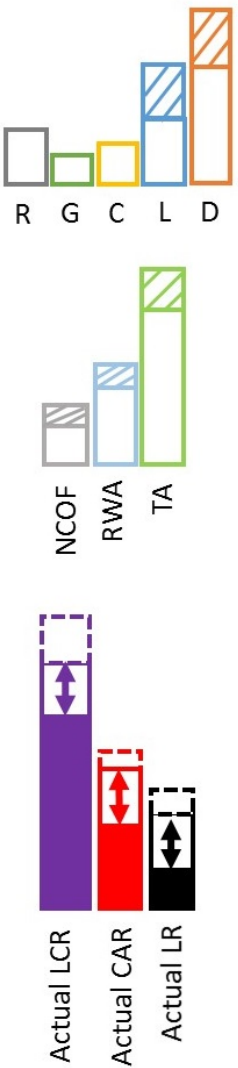

Abbreviations:

$\mathrm{R}$ : reserves

G: government bond

C: capital

L: loans

D: deposits

NCOF: net cash outflow

RWA: risk-weighted assets

TA: total assets

LCR: liquidity coverage ratio

CAR: risk-based capital adequacy ratio

LR: leverage ratio
Required LCR

Required CAR

Required LR

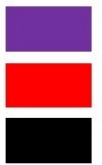

Figure 3: Changes in the components of bank balance sheet and monitor instruments under Basel III regulations after increasing the loan stock. (a) After making new loans in excess of due loan repayments, the stocks of loans and deposits increase while the stocks of reserves, government bonds and bank capital remain unchanged. (b) Along with the increase of the loan stock, banks are exposed to higher liquidity and solvency risks. As a result, the net cash outflow, risk-weighted assets and total assets rise accordingly. However, the amount of high quality liquid assets (including reserves and zero-risk-weight government bonds) and bank capital, which serve as the credit base for banks to guard against liquidity and solvency risks, do not change. (c) Because of the increasing denominators and the constant nominators, the actual liquidity coverage ratio, risk-based capital adequacy ratio and the leverage ratio drop and approach to their corresponding minimum requirements set by the Basel III regulations. Therefore, given no improvement of the bank's credit base, the implementation of prudential regulations casts a maximum limit for the amount of loans and deposits that can be created by the bank.

It is argued by some that the simple leverage ratio is a much more reliable guide and predictor of actual bank default than the risk-based ratio (Alessandri and Haldane, 2011; Blundell-Wignall and Roulet, 2013).

In essence, the Basel III accord sets a minimum limit on the banks' holdings of high liquid assets and core capital, which serve as the credit base to guard against the liquidity and solvency risks for banks to conduct the business of borrowing short and lending long. However, it is often 
difficult for banks to improve their credit base in the short-term or without the help of external forces. While individual banks can adjust their holdings of the stock of high liquid assets, the available stock of high liquid assets for the banking system as a whole is fundamentally dependent on central bank policies. For the capital stock to grow, a bank has to issue additional common shares or accumulate retained earnings, which will impair the bank's profitability performance in terms of reduced return to equity or lower dividend payout ratio. Therefore, given the current level of the credit base, the credit creation ability of banks is constrained by the prudential regulations. Specifically, as illustrated in Figure 3(a), when the lending flow exceeds the repayment flow, the stock of loans and deposits simultaneously increase. As a result, the amount of total assets rises. Meanwhile, the increase in the loan stock is accompanied by rising exposure to default risk, resulting in a higher quantity of risk-weighted assets. Similarly, higher liquidity risk comes with an increase in the deposit stock or other liabilities, which brings about greater expected net cash outflow. On the other hand, the amount of bank capital and that of high quality liquid assets such as reserves and government bonds with zero risk-weight are not directly affected by the behaviors of bank lending and loan repayment. In other words, compared to the quick easy expansion of the stocks of loans and deposits, changes in the banking system's liquidity and equity positions are much slower and more dependent on external forces. In consequence, as shown in Figure 3(c), the actual liquidity coverage ratio, risk-based capital adequacy ratio and leverage ratio usually decrease along with the increases in loans and deposits. When these ratios reach or come close to the minimum requirements of the Basel III accord, banks will become more cautious in making loans due to the high cost of regulation violation. ${ }^{6}$ In other words, in the absence of such regulations, there is no theoretical limit for the credit supply of banks before massive defaults or funding flights kick in. Therefore, given the minimum requirement of the concerned prudential regulations and the current level of the bank's credit base and risk conditions of its asset and liability, we can derive a maximum limit for the loans and deposits that can be created by the bank.

\section{The model}

To demonstrate the impacts of Basel III regulations on the credit creation process, we employ a stock-flow consistent dynamical model modified based on the work of $\mathrm{Li}$ et al. (2017). ${ }^{7} \mathrm{We}$ consider a representative commercial bank with a simplified balance sheet shown in Table. 1. On the asset side, there are three items: reserves $(R)$, government bonds with zero risk-weight $(B)$ and loans $(L)$ with an average risk-weight of $\gamma$. On the liability side, we only consider deposits $(D)$ and bank capital $(C)$. Following Krug et al. (2015), we do not make any distinction between core capital Tier 1 and other capital.

\footnotetext{
6 In order to increase the actual LCR,CAR and LR, banks may also increase the share of safe or short-term loans and raising more stable funds. However, the effects of these actions are marginal compared with the overall quantity control of loans and deposits.

7 Compared with the model in Li et al. (2017), we make a more realistic assumption about the commercial bank's balance sheet structure by considering bank capital and government bonds in addition to reserves, deposits and loans. Such extension allows us to explore the constraining effects of different prudential regulation including the LCR, CAR and LR regulations.
} 
Table 1: A simplified balance sheet for a representative commercial bank

\begin{tabular}{|c|c|}
\hline Asset & Liability \\
\hline Reserves $(R)$ & Deposits $(D)$ \\
\hline Government bonds $(G)$ & \\
\hline Loans $(L)$ & Capital $(C)$ \\
\hline
\end{tabular}

To focus our analyses on the impacts of prudential regulations on commercial bank behaviors, we assume that the demand for loans is always larger than the supply of loans and that the interest rate is constant and profitable for the bank. In addition, due to the reasons mentioned in the previous section, we suppose that the stocks of reserves, government bonds and bank capital are exogenously given. Also, banks are assumed to hold no voluntary buffer above the minimum capital or liquidity requirements. With these assumptions, we abstract from the real economy, loan demand and the price effect of varying interest rate while keeping only the minimum elements necessary in the study of the constraining effect of Basel III on money creation. These simplifications allow us to focus on the complexity of the multi-polar prudential regulation framework itself, which includes the difference in the standalone impact of individual policy instrument and their complicated interactions when simultaneously imposed. Moreover, the adopted stock-flow consistent framework guarantees the consistency of our analyses with both the accounting principle and the law of stock-flow motion. These properties make it easier to integrate our findings in more complicated stock-flow consistent models such as the inspiring work of Caiani et al. (2016) where the banking sector is considered to be special and not reduced to a mere financial intermediary.

Suppose time is discrete and the unit of each time step is one month. Due to the accounting consistency, the following identity between assets and liabilities should always hold:

$$
R(t)+G(t)+L(t)=D(t)+C(t) .
$$

The stocks of reserves, government bonds and bank capital are assumed to be always positive and exogenously given. In other words,

$$
\begin{aligned}
& R(t)=R, \\
& G(t)=G, \\
& C(t)=C .
\end{aligned}
$$

At each time $t$, changes in the stock of loans and deposits are both governed by the difference between the new bank lending flow $(L F)$ and the loan repayment flow $(R P)^{8}$, i.e.

$$
L(t+1)-L(t)=L F(t)-R P(t),
$$

\footnotetext{
8 In addition to bank lending and loan repayment, the stock of deposits will also be changed by the flows of cash deposits and withdrawal. For simplicity we assumes no cash and focus on the behaviors of lending and repayment.
} 


$$
D(t+1)-D(t)=L F(t)-R P(t) .
$$

For the initial period, we assume there are no loans $(L(1)=0)$ and $D(1)=L(1)+R(1)+$ $G(1)-C(1)=R+G-C$. Because the amount of deposits cannot be negative, $R+G-C \geq 0$ must hold.

For simplicity, we also assume all loans are amortized with an average maturity of $\theta$. In other words, a new loan made at month $t^{\prime}, L F\left(t^{\prime}\right)$, will be paid off at month $t^{\prime}+\theta$. Thus the amount of repayment for this loan due at month $t$, denoted as $R P_{t^{\prime}}(t)$, is

$$
R P_{t^{\prime}}(t)=\left\{\begin{array}{l}
0, t \neq t^{\prime}+1, t^{\prime}+2, \ldots, t^{\prime}+\theta ; \\
\frac{L F\left(t^{\prime}\right)}{\theta}, t=t^{\prime}+1, t^{\prime}+2, \ldots, t^{\prime}+\theta .
\end{array}\right.
$$

Thus, the total repayment flow due at time $t, R P(t)$, can be computed as the sum of repayments due for all loans made in the past $\theta$ periods, given by

$$
R P(t)=\left\{\begin{array}{l}
0, t=1 \\
\sum_{t^{\prime}=1}^{t-1} \frac{L F\left(t^{\prime}\right)}{\theta}, 1<t<\theta ; \\
\sum_{t^{\prime}=t-\theta}^{t-1} \frac{L F\left(t^{\prime}\right)}{\theta}, t \geq \theta .
\end{array}\right.
$$

As articulated in Section 2, the bank's decision of making new loans is constrained by prudential regulations because the credit base cannot be increased in the short term. Let us denote $L_{\max }$ as the maximum loan stock for the bank to satisfy the minimum regulatory requirement given the current level of credit base and exposures to risk. Because we do not consider the bank's voluntary holding of additional credit base, the increment of the outstanding loan stock $L(t)$ should be no more than its difference from the maximum loan stock $L_{\max }$, i.e.

$$
L(t+1)-L(t)=L F(t)-R P(t)=\rho\left(L_{\max }-L(t)\right),
$$

where $\rho(\rho \in[0,1])$ controls the speed at which $L(t)$ approaches to $L_{\max }$. From Equation (13), we can obtain the expression for the new lending flow as

$$
L F(t)=R P(t)+\rho\left(L_{\max }-L(t)\right) .
$$

When the dynamic model reaches the stock-flow equilibrium, all stocks and flows should be constant. Thus, supposing the system reaches equilibrium at time $t^{*}$, we should have $\forall t \geq t^{*}$,

$$
\begin{aligned}
& L(t)=L^{*}, \\
& D(t)=D^{*}, \\
& L F(t)=R P(t)=L F^{*}=R P^{*},
\end{aligned}
$$


where $L^{*}, D^{*}, L F^{*}$ and $R P^{*}$ denote respectively the equilibrium values of loans, deposits, the flow of new lending and the flow of repayment. Also, from Equations (14) and (17), we find that the equilibrium loan stock is at the maximum value permitted by the prudential regulation of concern, i.e.

$$
L^{*}=L_{\max } .
$$

In addition, by manipulating Equations (9), (12), (15) and (17) (details are shown in Appendix A), we can prove that

$$
L F^{*}=R P^{*}=\frac{2}{1+\theta} L^{*}, t \geq t^{*}
$$

We assume there is no cash in our model. The monetary base $M B$ is hence equal to the amount of reserves, and the broad money supply $M$ is hereafter the amount of deposits. Combining Equations (5) and (18), the broad money supply can be rewritten as a function of the maximum loan stock under the concerned prudential regulation as follows: ${ }^{9}$

$$
M=R+G-C+L_{\max } .
$$

Correspondingly, based on Equations (6), (7) and (8), the money multiplier $m$, defined as the ratio of the broad money supply and monetary base, is given by

$$
m=\frac{M}{M B}=1+\frac{G}{R}-\frac{C}{R}+\frac{L_{\max }}{R} .
$$

Henceforth, based on this model, we move on to examine the specific impacts of Basel III regulations on money creation.

\section{Impacts of Basel III regulations}

In this section, we will first analyze in Section 4.1 the standalone effect of individual regulation on credit creation by deriving the maximum limit on bank loans when only one regulatory instrument is imposed and solving for the corresponding equilibrium money supply and money multiplier. We will also briefly analyze the determinants of the money supply and the money multiplier under each condition. Then in Section 4.2, we will inspect the collective impact of the simultaneous imposition of all policy instruments, identify which of them is the binding constraint and analyze how the corresponding money multiplier changes across different economic states and with varying bank balance sheet condition.

\footnotetext{
9 Note that because we do not consider banks' voluntary holdings of excessive reserves and bank equities above the minimum prudential requirement, these expressions reflect the banking system's maximum ability to create money. Since our purpose is to evaluate the policy impact of the Basel III regulation on money creation rather than estimating the real values of the money supply and the money multiplier, we will focus on the relative changes in these values when the regulation of concern is different or when the economic condition varies.
} 


\subsection{Standalone impact of individual regulations}

The liquidity coverage ratio Assume the minimum requirement of LCR is $r_{L C R}$. The constraint in Equation (1) can be rewritten as

$$
r_{L C R} * N C O F \leq H Q L A .
$$

Since only reserves and government bonds with zero risk-weight are qualified as high quality liquid assets in our model, we have

$$
H Q L A=R+G
$$

As indicated in Equation (2), the net cash outflow is a function of the expected cash outflow and inflow within 30 days. In real world, the total expected cash outflow are calculated by multiplying the outstanding balances of various categories or types of liabilities and off-balance sheet commitments by the rates at which they are expected to run off or be drawn down, while the total expected cash inflow are calculated by multiplying the outstanding balances of various categories of contractual receivables by the rates at which they are expected to flow in. In our model, we assume the total cash outflow $(O F)$ comes from the potential loss of deposits, which is given by

$$
O F(t)=\mu D(t)
$$

where $\mu$ is the run-off ratio of deposit loss to total deposits. The total cash inflow $(I F)$ is supposed to be constituted of the expected loan repayment due in one month with a discount rate of $50 \% 10$ due to the assumption of stressed condition, i.e.

$$
I F(t)=0.5 R P(t)
$$

According to the definition of net cash outflow in the LCR regulation (Equation (2)), when the total expected inflow is not less than $75 \%$ of the total expected outflow, we have $N C O F(t)=O F(t)-0.75 O F(t)=0.25 O F(t)$; otherwise, the net cash outflow is the difference between outflow and inflow, that is, $N C O F(t)=O F(t)-I F(t)$. Putting these two conditions together with Equations (24) and (25), the following expression for the net cash outflow can be obtained:

$$
\operatorname{NCOF}(t)=\left\{\begin{array}{l}
0.25 \mu D(t), \operatorname{IF}(t) \geq 0.75 O F(t) ; \\
\mu D(t)-0.5 R P(t), \operatorname{IF}(t)<0.75 O F(t) .
\end{array}\right.
$$

\footnotetext{
${ }^{10}$ According to the official document regarding the LCR regulation provided by the Basel committee(Basel Committee on Banking Supervision, 2013), different inflow rates are set by the Basel III accord for different types of bank assets. For instance, the accord requires that a bank should assume that maturing reverse repurchase or securities borrowing agreement secured by Level 1 assets (which corresponds to overnment bonds and bank reserves in our model) will be rolled-over and will not give rise to any cash inflow (0\%). On the other hand, the inflow rate for non-HQLA assets varies from $0 \%-100 \%$ for different types of counterparties based on their abilities to fulfill debt obligations under stressed conditions. Here we take $50 \%$ as an exemplary inflow discount rate for the repayments received from outstanding bank loans. Discussions for relaxing this assumption are given in Appendix C.
} 
Next, let us consider the first condition, $\operatorname{IF}(t) \geq 0.75 O F(t)$, where the LCR regulation is equivalent to the following constraint:

$$
0.25 \mu r_{L C R} D(t) \leq R+G
$$

Due to the accounting consistency in Equation (5), we can rewrite the above inequality as a function of $L(t)$ :

$$
0.25 \mu r_{L C R}[R+G-C+L(t)] \leq R+G,
$$

When Equation (28) takes equality, the bank's actual capital adequacy ratio reaches the minimum policy requirement and the loan stock achieves its maximum value, i.e. $L(t)=L_{\max }$. With simple manipulations, it is easy to obtain that

$$
L_{\max }=\left(\frac{4}{\mu r_{L C R}}-1\right)(R+G)+C .
$$

Substituting Equation (29) into Equations (20) and (21), we have the equilibrium expressions for the broad money supply and money multiplier respectively as

$$
\begin{aligned}
& M=\frac{4(R+G)}{\mu r_{L C R}}, \\
& m=\frac{4}{\mu r_{L C R}}\left(1+\frac{G}{R}\right) .
\end{aligned}
$$

In order to examine the response of the bank's money creation capacity when there is a shock to the level of the monetary base under the constraint of the LCR regulation, ceteris paribus, we can take the partial derivatives of Equations (30) and (31) with respect to the level of bank reserves, the results of which are given as follows:

$$
\begin{aligned}
& \frac{\partial M}{\partial R}=\frac{4}{\mu r_{L C R}}>0, \\
& \frac{\partial m}{\partial R}=-\frac{4 G}{\mu r_{L C R} R^{2}}<0 .
\end{aligned}
$$

In other words, in this situation, when the central bank raises the monetary base, the broad money supply will also increase, but not by a constant money multiplier as in the case where the bank is constrained by the reserve requirement. Instead, the money multiplier falls with the increase of reserves.

Similarly, it can be inferred from Equation (30) that $\frac{\partial M}{\partial G}>0$, which demonstrates the positive dependence of the money supply on the amount of government bonds with zero-risk weight. In addition, we find that both the the money supply and the money multiplier are negatively dependent on the minimum policy ratio $r_{L C R}$ and on the deposit run-off ratio $\mu\left(\frac{\partial M}{\partial r_{L C R}}<0, \frac{\partial m}{\partial r_{L C R}}<0, \frac{\partial M}{\partial \mu}<\right.$ $\left.0, \frac{\partial m}{\partial \mu}<0\right)$. 
In the second condition where $I F(t)<0.75 O F(t)$, considering Equations (23) and (26), the LCR regulation in Equation (22) takes the following form:

$$
r_{L C R}[\mu D(t)-0.5 R P(t)] \leq R+G .
$$

Similarly, when $L(t)=L_{\max }$, the above inequality takes equality. Based on Equations (17), (19) and (18), we know that $\forall t \geq t^{*}, R P(t)=\frac{2}{1+\theta} L_{\max }$. Also, from Equation (5), (16) and (18), we can have $\forall t \geq t^{*}, D(t)=R+G-C-L_{\max }$. By substituting the expressions of $R P(t)$ and $D(t)$ in terms of $L_{\max }$ into Equation (34) with a few manipulations, we can obtain the expression for the maximum loan stock as follows:

$$
L_{\max }=\frac{(1+\theta)\left[(R+G)\left(1-\mu r_{L C R}\right)+\mu r_{L C R} C\right]}{r_{L C R}[\mu(1+\theta)-1]} .
$$

As a result, the equilibrium money supply and money multiplier are respectively given by

$$
\begin{aligned}
& M=\frac{(R+G)\left(1+\theta-r_{L C R}\right)+r_{L C R} C}{r_{L C R}[\mu(1+\theta)-1]}, \\
& m=\frac{\left(1+\frac{G}{R}\right)\left(1+\theta-r_{L C R}\right)+r_{L C R} \frac{C}{R} .}{r_{L C R}[\mu(1+\theta)-1]} .
\end{aligned}
$$

Correspondingly,

$$
\begin{aligned}
& \frac{\partial M}{\partial R}=\frac{1+\theta-r_{L C R}}{r_{L C R}[\mu(1+\theta)-1]}>0, \\
& \frac{\partial m}{\partial R}=-\frac{\left(1+\theta-r_{L C R}\right) G+r_{L C R} C}{r_{L C R}[\mu(1+\theta)-1] R^{2}}<0,
\end{aligned}
$$

which indicates that after a positive shock to the monetary base, the broad money supply will increase, but the size of the increment decreases with the scale of reserves. Again the money multiplier is not a constant as in the case where the banking system is only regulated by the reserve requirement. In addition, both the money supply and money multiplier respond negatively to the increase in the minimum requirement of $\operatorname{LCR}\left(\frac{\partial M}{\partial r_{L C R}}<0, \frac{\partial m}{\partial r_{L C R}}<0\right)$. Furthermore, we find that the money supply is not only an increasing function of the bank's holdings of government bonds $\left(\frac{\partial M}{\partial G}>0\right)$, but also of capital $\left(\frac{\partial M}{\partial C}>0\right)$. In other words, the banking system's ability to create money is higher when it holds more capital or government bonds.

Apart from the amount of high quality liquid assets and bank capital, we see from $\frac{\partial M}{\partial \mu}<$ $0, \frac{\partial M}{\partial \theta}<0, \frac{\partial m}{\partial \mu}<0, \frac{\partial m}{\partial \theta}<0$ that the reduction in the bank's exposure to liquidity risk, either due to more stable debt financing sources or a shortening of the average maturity of loans, will also lead to increases in both the money supply and the money multiplier.

Because the expressions for the expected cash inflow and $I F^{*}$ and $O F^{*}$ in the equilibrium are respectively

$$
I F^{*}=0.5 R P^{*}=\frac{L^{*}}{1+\theta},
$$




$$
O F^{*}=\mu D^{*}
$$

we can rewrite the conditions of $I F^{*} \geq 0.75 O F^{*}$ and $I F^{*}<0.75 O F^{*}$ as a function of $\mu, \theta, R, G, C$ following the manipulations shown in B. In specific, the two conditions are respectively equivalent to $\mu \leq \frac{4\left(1+\frac{G}{R}\right)}{\left(3 \theta+3+r_{L C R}\right)\left(1+\frac{G}{R}\right)-\frac{C}{R} r_{L C R}}$ and $\mu>\frac{4\left(1+\frac{G}{R}\right)}{\left(3 \theta+3+r_{L C R}\right)\left(1+\frac{G}{R}\right)-\frac{C}{R} r_{L C R}}$.

In summary, the full expressions for the equilibrium money supply and money multiplier are respectively given by

$$
\begin{aligned}
& M_{L C R}=\left\{\begin{array}{l}
\frac{4(R+G)}{\mu r_{L C R}}, \mu \leq \frac{4\left(1+\frac{G}{R}\right)}{\left(3 \theta+3+r_{L C R}\right)\left(1+\frac{G}{R}\right)-\frac{C}{R} r_{L C R}} ; \\
\frac{(R+G)\left(1+\theta-r_{L C R}\right)+r_{L C R} C}{r_{L C R}[\mu(1+\theta)-1]}, \mu>\frac{4\left(1+\frac{G}{R}\right)}{\left(3 \theta+3+r_{L C R}\right)\left(1+\frac{G}{R}\right)-\frac{C}{R} r_{L C R}},
\end{array}\right. \\
& m_{L C R}=\left\{\begin{array}{l}
\frac{4\left(1+\frac{G}{R}\right)}{\mu r_{L C R}}, \mu \leq \frac{4\left(1+\frac{G}{R}\right)}{\left(3 \theta+3+r_{L C R}\right)\left(1+\frac{G}{R}\right)-\frac{C}{R} r_{L C R}} ; \\
\frac{\left(1+\frac{G}{R}\right)\left(1+\theta-r_{L C R}\right)+r_{L C R} \frac{C}{R}}{r_{L C R}[\mu(1+\theta)-1]}, \mu>\frac{G}{\left(3 \theta+3+r_{L C R}\right)\left(1+\frac{G}{R}\right)-\frac{C}{R} r_{L C R}} .
\end{array}\right.
\end{aligned}
$$

The risk-based capital adequacy ratio For simplicity, our model does not distinguish the quality of bank capital and assumes all capital are qualified in the calculation of the risk-based capital adequacy ratio. Denoting $r_{C A R}$ as the minimum policy requirement, we have the following expression for the CAR regulation:

$$
C(t) \geq r_{C A R} * R W A(t),
$$

where $C(t)=C$ and the amount of risk-weighted assets $R W A$ is computed as the product of bank assets and their corresponding risk-weight, as given by

$$
R W A(t)=0 *(R+G)+\gamma L(t)=\gamma L(t) .
$$

When Equation (44) takes equality, the banking system reaches its maximum credit creation ability, which yields

$$
L_{\max }=\frac{C}{\gamma r_{C A R}} .
$$

Substituting Equation (46) into Equations (20) and (21), we have the equilibrium expressions for the money supply and the money multiplier as follows:

$$
\begin{aligned}
& M_{C A R}=R+G+\left(\frac{1}{\gamma r_{C A R}}-1\right) C . \\
& m_{C A R}=1+\frac{G}{R}+\left(\frac{1}{\gamma r_{C A R}}-1\right) \frac{C}{R} .
\end{aligned}
$$

Furthermore, it can be demonstrated that

$$
\frac{\partial M_{C A R}}{\partial R}=1>0
$$




$$
\frac{\partial m_{C A R}}{\partial R}=-\frac{G+\left(\frac{1}{\gamma_{C A R}}-1\right) C}{R^{2}}<0 .
$$

Similar as in the case of LCR regulation, the broad money supply is an increasing function of the monetary base whereas the money multiplier is a decreasing function of the monetary base. As indicated by $\frac{\partial M_{C A R}}{\partial R}=1$, the increase of reserves will not have any multiplier effect on the broad money supply.

In addition, the broad money supply is positively dependent on the amount of government bonds and bank capital $\left(\frac{\partial M}{\partial G}>0, \frac{\partial M}{\partial C}>0\right)$. Moreover, we can see that the values of money supply and money multiplier also depend on the average default risk of bank loans $(\gamma)$ and the minimum policy requirement of CAR $\left(r_{C A R}\right)$ in that $\frac{\partial M}{\partial \gamma}<0, \frac{\partial m}{\partial \gamma}<0, \frac{\partial M}{\partial r_{C A R}}<0, \frac{\partial m}{\partial r_{C A R}}<0$.

The leverage ratio With the minimum requirement of leverage ratio being $r_{L R}$, the bank faces the following constraint:

$$
C(t) \geq r_{L R} * T A(t),
$$

where $C(t)=C$ and $T A(t)=R+G+L(t)=D(t)+C$. When equality is taken, the loan stock reaches its maximum limit, as given by

$$
L_{\max }=\frac{C}{r_{L R}}-R-G
$$

Correspondingly, the equilibrium money supply and money multiplier are

$$
\begin{aligned}
& M_{L R}=\left(\frac{1}{r_{L R}}-1\right) C, \\
& m_{L R}=\left(\frac{1}{r_{L R}}-1\right) \frac{C}{R} .
\end{aligned}
$$

The responses of money supply and money multiplier to reserve shocks are respectively given by

$$
\begin{aligned}
& \frac{\partial M_{L R}}{\partial R}=0, \\
& \frac{\partial m_{L R}}{\partial R}=-\left(\frac{1}{r_{L R}}-1\right) \frac{C}{R^{2}}<0 .
\end{aligned}
$$

As shown by Equation (53), the determinants of the broad money supply only include the minimum policy requirement of LR and the amount of bank capital. Thus, the only way to increase the money supply under the given LR regulation is to increase the amount of bank capital $\left(\frac{\partial M_{L R}}{\partial C}>0\right)$. In other words, increasing the monetary base will have no impact on the banking system's broad money supply and the only consequence of this action is the reduction of the money multiplier.

Thus far, we have examined the standalone impact of each individual regulation on the bank's ability to lend and create money. Table 2 summarizes the above results, from which four key 
observations can be made: 1) there is a positive relation between the monetary base and the broad money aggregate under all regulations, except for the LR regulation, under which the broad money aggregate is independent from the monetary base; and 2) the tightening of the Basel III regulations, similar as the reserve requirement, will have a negative impact on the banking system's ability to create money; and 3) in contrast to the constant money multiplier under the reserve requirement, the money multiplier under the Basel III accord is a decreasing function of the monetary base; and 4) when being constrained by different prudential regulations, the money creation process is sensitive to different types of economic changes. For instance, the change in the level of bank capitals can affect the money supply and the money multiplier only when the banking system is constrained by capital-based requirements of the CAR and LR regulations. On the other hand, the stability of the bank's debt-based financing source and the maturity structure of loans only matter when the LCR regulation is taking effect.

\subsection{Collective impact of multiple regulations under different economic conditions}

"Regulatory measures must build upon each other and be interlocked to set consistent incentives. Otherwise, we run the risk of individual measures conflicting with each other. Such a lack of consistency might lessen the desired effects of the new regulations or even negate them entirely. Impact studies are an important tool in this context. "

—Dombret (2013), Member of the Executive Board of the Deutsche Bundesbank

Up till now, we have obtained the equilibrium expressions for the broad money supply and the money multiplier when the bank only face one regulation. However, without a comprehensive analysis when multiple policy instruments simultaneously take effect, the evaluation of the impacts of Basel III on money creation is incomplete. When the bank is subject to more than one prudential regulations, its credit creation capacity is bound by the most stringent constraint. Therefore, by comparing the values of the money multiplier derived for each individual instrument in Equations (43), (48) and (54) and solving for the minimum money multiplier, we can determine the effective binding regulation and obtain the corresponding expression for the money multiplier when multiple regulations are imposed at the same time, i.e.

$$
m=\min \left\{m_{L C R}, m_{C A R}, m_{L R}\right\} .
$$

Correspondingly, the boundary conditions that mark the transitions of the binding constraint can be derived when the expressions for the money multiplier corresponding to each two regulations take the same value. For the sake of simplicity, we denote the ratio of government bonds to reserves as $g=\frac{G}{R}$ and the ratio of bank capital to reserves as $c=\frac{C}{R}$. Specifically, the boundary condition between the LCR and CAR regulations is given by

$$
\begin{aligned}
\frac{4(1+g)}{\mu r_{L C R}} & =1+g+\left(\frac{1}{\gamma r_{C A R}}-1\right) c, \\
\text { or } \frac{(1+g)\left(1+\theta-r_{L C R}\right)+c r_{L C R}}{r_{L C R}[\mu(1+\theta)-1]} & =1+g+\left(\frac{1}{\gamma r_{C A R}}-1\right) c .
\end{aligned}
$$



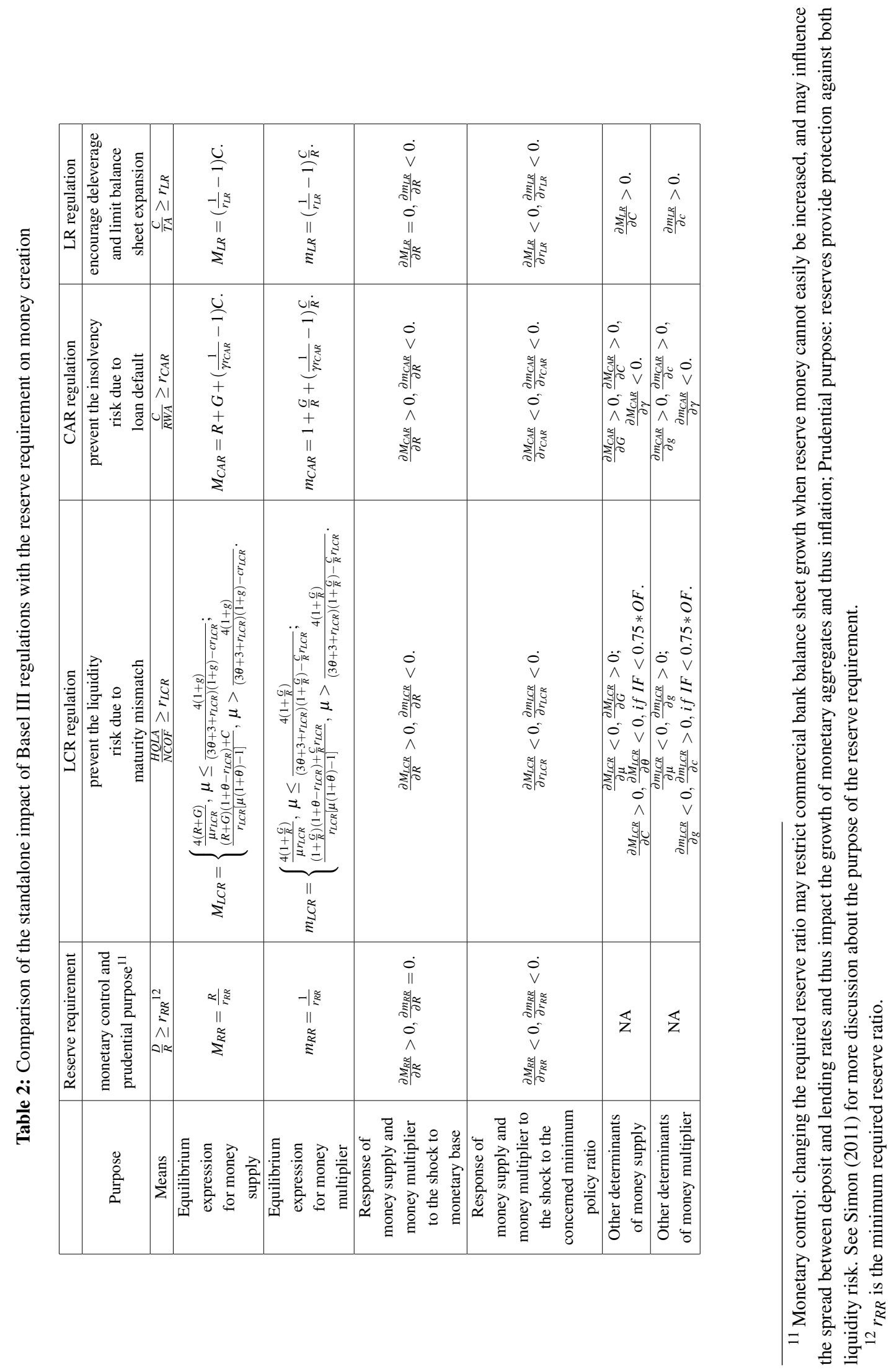
The boundary condition between the LCR and LR regulations is

$$
\begin{aligned}
\frac{4(1+g)}{\mu r_{L C R}} & =\left(\frac{1}{r_{L R}}-1\right) c, \\
\text { or } \frac{(1+g)\left(1+\theta-r_{L C R}\right)+c r_{L C R}}{r_{L C R}[\mu(1+\theta)-1]} & =\left(\frac{1}{r_{L R}}-1\right) c .
\end{aligned}
$$

The boundary condition between the CAR and LR regulations is

$$
1+g+\left(\frac{1}{\gamma_{C A R}}-1\right) c=\left(\frac{1}{r_{L R}}-1\right) c .
$$

For the two expressions for LCR regulation to take identity,

$$
\frac{4(1+g)}{\mu r_{L C R}}=\frac{(1+g)\left(1+\theta-r_{L C R}\right)+c r_{L C R}}{r_{L C R}[\mu(1+\theta)-1]} .
$$

Due to the mathematical complexity of the expression for the money multiplier in Equation (57), we set $r_{L C R}=100 \%, r_{C A R}=7 \%, r_{L R}=3 \%$ in the following analyses and use Figure 4 as the major illustration for analysis. By setting the monetary base to be constant, we focus on the transitions of the effective binding regulation and the relative changes in the equilibrium values of the money multiplier across different economic states and bank balance sheet conditions.

To begin with, we categorize the variables concerned into two groups. The first group includes the variables that determine the features of the bank's uses of funds: the average maturity of loans $\theta$ and the average default risk of loans $\gamma$. The second group contains variables that characterize the bank's sources of funds: the average run-off ratio of bank liabilities $\mu$ and the capital to reserve ratio $c$. For the uses of funds, loans with longer maturity $\theta$ and higher default risk $\gamma$ are often associated with higher profits. Nevertheless, these loans will also expose the bank to higher probabilities of maturity mismatch and insolvency problems. For the source of funds, the debt-financing source is usually stable during good times (low $\mu$ ) but becomes flighty during economic downturns (high $\mu$ ). The amount of bank capital, on the other hand, depends on how the bank strikes a balance between profitability performance and risk resilience as well as on how difficult it is to raise new equity.

Based on this reasoning, we vary the average maturity $\theta$ and default risk $\gamma$ and show them respectively in the horizontal and vertical axes in all panels in Figure 4. Correspondingly, the equilibrium values of the money multiplier are computed based on Equation (57) and indicated by color. The color scale is logarithmic so as to accommodate for the large variations in the value of the money multiplier across different conditions. In order to comprehensively examine the role of the bank's balance sheet structure and the underlying economic condition in money creation, we consider three scenarios: 1) the bank holds high level of capital $c=2$ and faces low run-off ratio of debt financing $\mu=0.1$ (Figure 4(a)); and 2) the bank holds low level of capital $c=0.8$ and faces low run-off ratio of debt financing $\mu=0.1$ (Figure 4(b)); and 3) the bank holds high level of capital $c=2$ and faces high run-off ratio of debt financing $\mu=0.55$ (Figure 4(c-d)). In particular, Figure 4(c) and (d) differ in terms of the range for the average maturity $(\theta \in[1,6]$ for (c) and $\theta \in[7,180]$ for (d)), so as to give the best resolution for the variation in the money multiplier. For all scenarios, the government bonds to reserve ratio $g$ is kept fixed and equal to 3 . Choice of the 
(a) $\mathrm{c}=2, \mu=0.1$

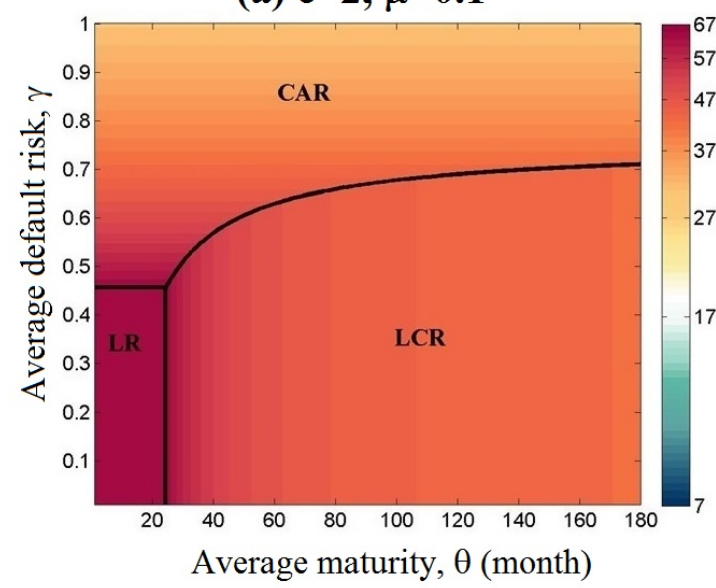

(c) $c=2, \mu=0.55(\theta \leq 6)$

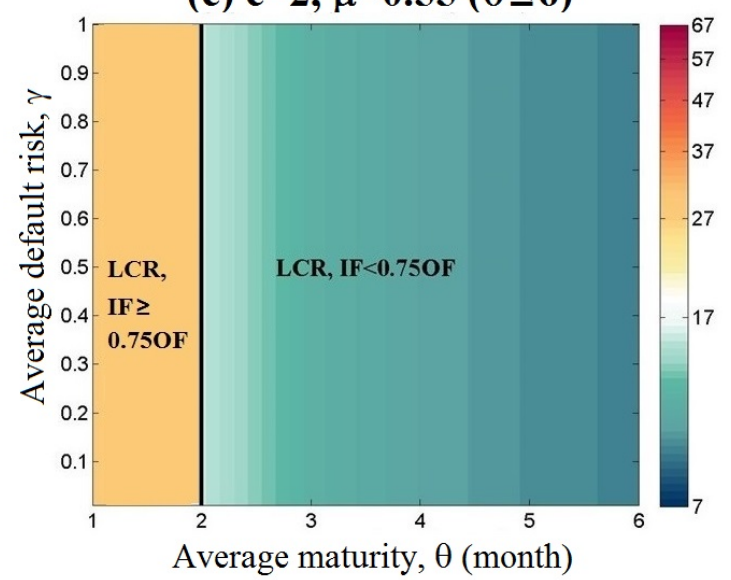

(b) $\mathrm{c}=2, \mu=0.1$

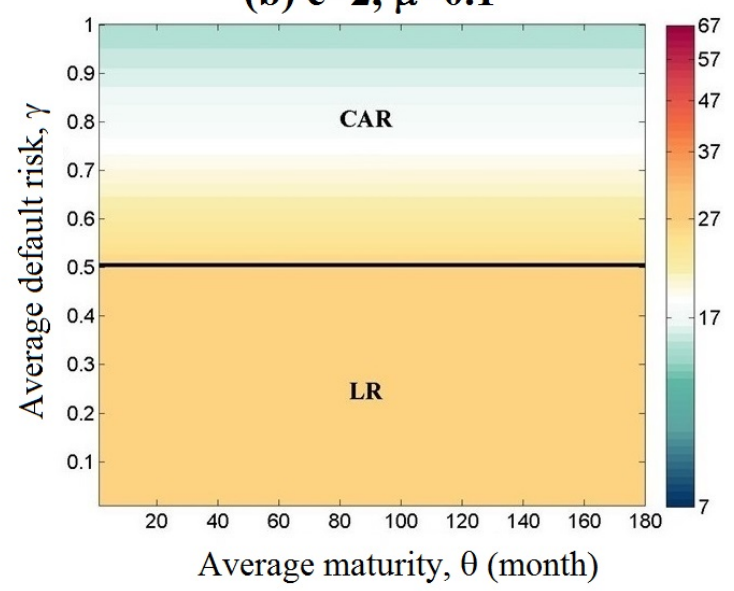

(d) $\mathrm{c}=2, \mu=0.55(\theta>6)$

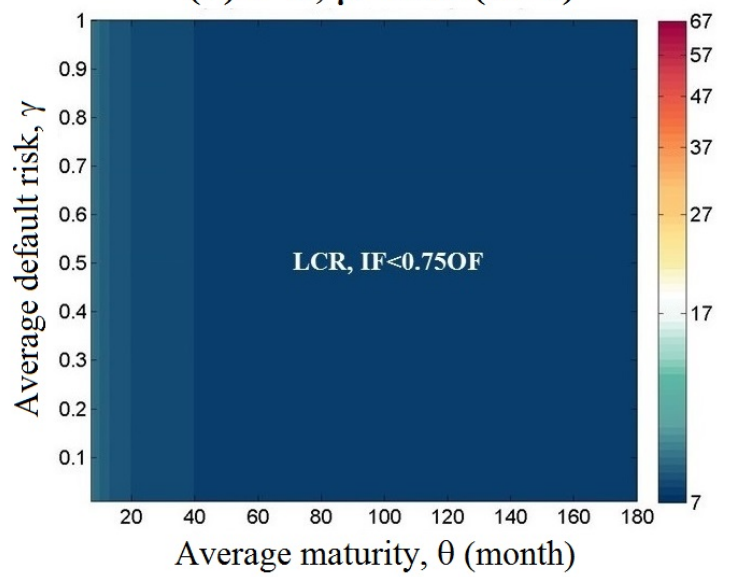

Figure 4: Binding regulations and corresponding values of the equilibrium money multiplier as a function of the average default risk $\gamma(\gamma \in[0,1])$ and the average maturity $\theta(\theta \in[1,180])$ of loans under three representative scenarios with different combinations of the capital-to-reserve ratio $c$ and the deposit run-off ratio $\mu$. The values of the money multiplier are computed according to Equation (57) and indicated by color. The color scale is logarithmic so as to accommodate for the large distinctions in the value of the money multiplier across different conditions. Boundaries between different binding regulations are computed based on Equations (58), (59), (60), (61) and presented by black lines that separate the state space of $\gamma$ and $\theta$. (a) Scenario 1: the bank holds high level of capital with $c=2$ and faces low run-off ratio $\mu=0.1$. In this case, all three regulations can be observed in the parameter space of the maturity length $\theta$ and default risk $\gamma$ of loans. (b) Scenario 2: the bank faces low run-off ratio $\mu=0.1$ but holds low level of capital $c=0.8$. Only capital requirements can be observed in the parameter space. (c-d) Scenario 3: The bank holds high level of capital $c=2$ but faces high liability run-off ratio $\mu=0.55$ with (c) demonstrating results for maturity less than 6 months and (d) for maturity larger than 6 months. All results are obtained for $g=3$. In both (c) and (d), the LCR regulation alone takes effect. In all three scenarios, the money multiplier is generally higher with high capital holdings, low run-off ratio, low default risk and short maturity length. 
values of parameter $c$ in these examples is made based on the statistics of the U.S. banking system in the from 1992 to 2009 as shown in Table 3 in Appendix D. The exemplary values of parameter $\mu$ are determined based on the estimated run-off ratios for different types of liabilities listed in the official document from the Basel Committee on the liquidity coverage ratio regulation (Basel Committee on Banking Supervision, 2013). It is noteworthy that these scenarios are representative cases, while there are other scenarios where the interactions of the three prudential regulations and the values for the money multipliers are different. Yet such differences are in scale, not in type, which will not lead to qualitative changes in our conclusions. Next, we will base our analysis on these three scenarios and demonstrate how the binding regulation changes with economic situation and how the bank's credit creation ability is affected.

Figure 4(a) presents the benchmark case for Scenario 1 where all three regulations can be the effective binding constraint when the default risk of loans $\gamma$ varies from 0 to 1 and the average loan maturity $\theta$ changes from 1 month to 15 years. When the risk of loan default is high, the bank is bound by the CAR regulation. When the default risk is relative low and average loan maturity is long, the LCR regulation takes effect. When the assets are both low in risk and short in maturity, the LR regulation serves as a backstop constraint on money creation. Consistent with our result on the dependence of the money multiplier on loan maturity and default risk for individual regulations, the money multiplier drops when the bank holds assets with longer maturity and higher default risk. However, due to the piece-wise expression of the money multiplier, the same increment in $\theta$ and $\gamma$ when their values are at different initial levels may have distinct effects on the value of the multiplier.

In Scenario 2, there is no change in the bank's debt-based financing source but the level of bank capital is much lower than that in Scenario 1. As a result, the capital constraint becomes the bank's biggest concern. As shown in Figure 4(b), only capital requirements are taking effect. The CAR and LR regulations are respectively responsible for the situations of higher and lower default risk. Compared to the first scenario, the bank's ability to create money significantly drops with the decrease in its capital holdings, as indicated by the lower values of the money multiplier for the same default risk and loan maturity combination in Figure 4(b) than (a). The money multiplier is negatively dependent on the default risk whereas it is unaffected by changes in the average maturity of loans.

In addition, Figure 4(c-d) demonstrates the changes in the money multiplier in Scenario 3 where bank capital is sufficient but the run-off ratio is high. In this scenario, regardless of the average maturity and risk of loans, the bank is bound only by the LCR regulation. This result corresponds to the phenomenon of extreme liquidity shortage during economic downturns when the roll-over of short term debt financing such as wholesale fundings are unlikely to happen or when depositors or other debtors for the bank start to withdraw funds due to risk aversion during market panic. Even though the bank's capital holdings are still high, we observe a significant decrease in the money multiplier in Figure 4(c-d) compared to Figure 4(a) due to the instability of its debt financing. Moreover, the money multiplier under this situation is only dependent on the length of loan maturity yet such dependence is a discrete function due to the piece-wise definition of the net cash outflow in LCR regulation. 
As shown in Figure 4(c), when the average loan maturity is extremely short, i.e. less than 2 months, the net cash outflow is solely determined by the expected cash outflow. In this case, the money multiplier is independent of the average loan maturity and loan default risk and is generally lower than in Scenario 1 and 2. When the average loan maturity is longer than 2 months (Figure 4(d)), the net cash outflow is governed by the difference between the total cash outflow and cash inflow. In this case, the bank faces significant loss in its funding source and, at the same time, experience difficulty in claiming its own funds back. The money multiplier is a decreasing function of the average loan maturity: for an average maturity of 6 months, the money multiplier has already decreased to less than 9,1/6 of the maximum value in Scenario 1. Nevertheless, the decline in the multiplier due to the incremental increase in loan maturity to more than 6 months is extremely marginal.

Comparing all four panels in Figure 4, we can observe that there are large distinctions in the value of the money multiplier as well as in the dependence of the multiplier on the underlying economic environment and bank balance sheet structure. Such distinctions result both from the transition of the effective binding regulation that serve as the most stringent constraint on lending activities, and from the variation in the bank's ability to create money under the same effective binding regulation but with different balance sheet structures in changing economic condition. Generally speaking, the LCR regulation acts as the dominant constraint when the bank is most endangered by the liquidity risk, either due to insufficient reserve buffer in proportion to the maturity mismatch, or due to unexpected deterioration of the bank debt market. On the other hand, when the shortage of capital buffer and the insolvency risk are the bank's biggest concern, capital-based regulations take the leading role in constraining bank activities, with the CAR and the LR regulations respectively being responsible for the high and the low default risk condition. Furthermore, as a result of the transitions of the effective binding constraint, the dependence of the money multiplier on the parameters related to the bank balance sheet structure are mostly nonlinear and sensitive to changes in the underlying economic condition. Consequently, policy makers should expect greater uncertainty in the impacts of monetary shocks on the money and credit supply in unstable economic environment, as well as for more diversity in the responses of banks with different balance sheet structures to the same shock.

In conclusion, three key findings can be summarized from Figure 4: 1) the effective binding regulation, by which the bank's ability to create money is constrained, varies across different economic states and bank balance sheet conditions; 2) due to the transition of the effective binding regulation, the money multiplier depends on the parameters related to the economic state and bank balance sheet condition in a nonlinear way; 3 ) in general, the money multiplier increases when the banking system holds higher level of capital, assets with shorter maturity and lower default or depreciation risk, and more stable debt-based financing sources.

\section{Concluding remarks}

This paper is inspired by pioneering works on rethinking the roles of the banking system in money creation. We contribute to this line of thoughts by emphasizing the important roles of prudential regulation in money creation and by delineating why and how these regulations take effect. In 
addition, by providing a detailed theoretical analysis of how Basel III regulations impact on money creation, our work lays the foundation for more comprehensive studies on the macroeconomic impact of Basel III on economic growth. The aim of the Basel III accord is to improve the resilience of the banking system and prevent future crisis. However, it may also bear the cost of restricting financial activities and downsizing the loan and money supply by the banking system, especially when there are imperfections and frictions in the financial markets for bank capital and high quality liquid assets. Taking such economic conditions into consideration, we re-examine the money creation process, under the assumption that the bank cannot increase its capital and liquidity buffers at will, but has to guarantee that these safety buffers are sufficient according to the standards of concerned prudential regulations to guard against the liquidity and insolvency risks undertaken during money creation.

In particular, we study three pillar regulations in the Basel III accord, including not only the enhanced risk-based capital adequacy regulation but also the newly proposed requirements on the leverage ratio and the liquidity coverage ratio. Using both graphical illustrations and a dynamic stock-flow consistent model, we elaborate on the central roles of commercial banks in money creation and the mechanism by which prudential regulations affect bank lending and money supply. For each prudential regulation, we have studied their standalone impact on money creation by obtaining the equilibrium expressions for the broad money supply and money multiplier and analyzing their corresponding determinants. We find that the money multiplier, instead of being constant as assumed in the traditional FRT, is a decreasing function of the monetary base under all three prudential regulations. In addition, we demonstrate that the determinants of the banking system's capacity of money creation are regulation-specific, due to the differences in the mechanisms by which different prudential regulations take effect. Specifically, under the LCR regulation, the loosening of the minimum requirement of LCR, the shortening of loan maturity, the enhancement in the stability of the bank's debt financing sources, the increase in the bank's holdings of bank capital and government bonds are all possible causes for the increase of the money supply. Under the CAR regulation, factors affecting the money creation process include the minimum requirement of CAR, the default risk of loans, the amount of bank capital and government bonds. On the other hand, the money supply under the LR requirement alone is solely dependent on the bank's capital holdings. In other words, when the bank only faces the LR regulation, increasing the monetary base will have no impact on the broad money supply. This result echoes the work of Martin et al. (2016) which demonstrates several scenarios where changes in bank reserves will have no or even negative impact on the bank's credit supply.

Furthermore, we also consider the simultaneous imposition of all three regulations and how their interactions make a difference in the money creation process. As the bank's capacity for money creation is bound by the most rigid constraint, the money multiplier under the collective influences of multiple regulations is obtained as the minimum value of the multipliers under each individual regulation. For three representative scenarios of different financing source conditions for the bank, we demonstrate the transitions of the effective binding regulation and corresponding changes in the money multiplier when there are variations in the risk and maturity structure of the bank's uses of funds. We find that the money creation capacity of the banking system is generally 
greater when its sources of funds contain sufficient capital and stable liabilities and its uses of funds entail less risk and shorter maturity.

From these observations, several policy implications can be drawn. To begin with, the new Basel regulations, in spite of their prudential purposes for enhancing financial stability, could also have a constraining effect on the banking system's credit and money supply, which overlaps with the functions of monetary policy instruments. In other words, apart from changing the monetary base or the required reserve ratio, varying the minimum regulatory requirements for the LCR, CAR and LR can achieve similar impacts on the broad money aggregate. This can have both an optimistic interpretation, that the implementation of the new Basel regulations adds to the policy makers' toolkit for managing the financial system and the macro-economy, as well as a negative implication, that there might be potential conflicts between these prudential and monetary instruments, which requires upgraded coordination of the central bank and the banking supervision authority.

In addition, as a result of the variations in the constraining effects of different prudential regulations on money creation, policy makers are expected to be confronted with more complicated reactions from banks subject to these regulations. On the one hand, the traditional monetary transmission channel from the monetary base to the broad money aggregate may not be effective anymore when a bank is bound by the LR regulation, or will become less efficient when the LCR or the CAR regulation replaces the reserve requirements and serves as the bank's regulatory constraint. On the other hand, since the extent to which the monetary aggregate increases with the expansion of the monetary base becoming more sensitive to the underlying economic condition and more dependent on the bank balance sheet structure under the new Basel regulations than under the traditional reserve requirement, it is increasingly challenging for the policy makers to predict the consequences of their actions and determine the appropriate strength of the policy shock. Such policy conundrum will be further compounded by the transition of the effective binding constraint on individual banks across different economic conditions, when they are subject to multiple prudential instruments at the same time. Therefore, as indicated by Goodhart's Law that "any observed statistical regularity will tend to collapse once pressure is placed upon it for control purposes"(Goodhart, 2006, 2013), the collapse of the stability of the money multiplier in recent years may well be interpreted as Goodhart's Law in action, with the implementation of new prudential regulations being a direct or indirect catalyst.

Lastly, while it is vital for the policy makers to prepare for the constraining effects of the new Basel regulations on the banking system's money and credit creation activities, it is also important to be aware of the factors that could mitigate such constraints, but are not considered in the current analysis. Despite that the simplicity of our model is regarded as a merit in demonstrating the mechanics of the money creation process, we would also like to point out several potential limitations. The first limitation lies in the simplification of the bank behavior. Specifically, when there is an increase in the minimum prudential requirement, the regulated bank may not respond by cutting back on the quantity of its credit and money supply, but by adjusting the quality of its balance sheet items (e.g. lend to borrowers with lower default risk or reduce the maturity mismatch between its assets and liabilities). Moreover, the bank's actual capital ratios can also be bolstered by reserving more retained earnings, or as argued by Werner (2010), by new bank equity purchases 
that are fueled by the money created by the bank, so that no cutbacks on lending activities are needed. Such reactions should be attended more extensively in studies that focus on the impacts of prudential regulations over a longer term. Second, although we argue that taking the levels of government bonds and bank reserves as exogenously given is a reasonable assumption because these variables cannot be determined by the commercial bank alone at an aggregate level, this may not be applicable at the level of individual banks. For this reason, relaxing such assumptions and introducing heterogeneity into the analytical framework would be a fruitful attempt in the future. Third, it is noteworthy that we have followed a partial equilibrium approach, which puts the commercial bank in the center of discussion and abstracts from the behaviors of other agents, as in the textbook money creation model. Integrating the current analysis with more sophisticated descriptions of agents such as the borrowers, depositors and bank equity owners would be a worthwhile next step. Granting that these limitations be better addressed, the policy implications from our results are likely to hold withal. While we cannot exclude the possibility of the contrary, economists who believe that the new Basel regulations will have no impact on the mechanics of money creation should clarify whether the financial frictions in relevant markets are considered and articulate the real-world evidence that support their assumptions.

Acknowledgements This work was supported by the National Natural Science Foundation of China (Grant No. 61773069) and the Fundamental Research Funds for the Central Universities (Grant No.2015KJJCA06). Moreover, we are grateful to the corresponding Editor, two anonymous referees and other readers for their valuable suggestions and comments.

\section{References}

Abdul Karim, Z., Azman-Saini, W., and Abdul Karim, B. (2011). Bank lending channel of monetary policy: dynamic panel data study of Malaysia. Journal of Asia-Pacific Business, 12(3): 225-243. URL https://mpra.ub.uni-muenchen. de/26157/1/MPRA_paper_26157.pdf.

Ábel, I., Lehmann, K., and Tapaszti, A. (2016). The controversial treatment of money and banks in macroeconomics. Financial and Economic Review, 15(2): 33-58. URL https://papers.ssrn.com/sol3/papers.cfm?abstract_id=2819745.

Aiyar, S., Calomiris, C. W., and Wieladek, T. (2016). How does credit supply respond to monetary policy and bank minimum capital requirements? European Economic Review, 82: 142-165. URL https://doi.org/10.1016/j.euroecorev. 2015.07.021.

Albertazzi, U., and Marchetti, D. J. (2010). Credit supply, flight to quality and evergreening: an analysis of bank-firm relationships after Lehman. Discussion paper 756, Bank of Italy. URL http://www.bancaditalia.it/pubblicazioni/ temi-discussione/2010/2010-0756/en_tema_756.pdf.

Alessandri, P., and Haldane, A. G. (2011). Banking on the State. In The International Financial Crisis: Have the Rules of Finance Changed?, pages 169-195. World Scientific. URL http://www.worldscientific.com/worldscibooks/10. $1142 / 7865$.

Allen, B., Chan, K. K., Milne, A., and Thomas, S. (2012). Basel III: Is the cure worse than the disease? International Review of Financial Analysis, 25: 159-166. URL https://doi.org/10.1016/j.irfa.2012.08.004.

Altunbaş, Y., Fazylov, O., and Molyneux, P. (2002). Evidence on the bank lending channel in Europe. Journal of Banking \& Finance, 26(11): 2093-2110. URL https://doi.org/10.1016/S0378-4266(02)00201-7. 
Angelini, P., Clerc, L., Cúrdia, V., Gambacorta, L., Gerali, A., Locarno, A., Motto, R., Roeger, W., Van den Heuvel, S., and Vlček, J. (2015). Basel III: Long-term Impact on Economic Performance and Fluctuations. The Manchester School, 83(2): 217-251. URL https://doi.org/10.1111/manc.12056.

Basel Committee on Banking Supervision (2011). Basel III: A global regulatory framework for more resilient banks and banking systems. Bank for International Settlements. URL http://www.bis.org/publ/bcbs189.htm.

Basel Committee on Banking Supervision (2013). The Liquidity Coverage Ratio and liquidity risk monitoring tools. Bank for International Settlements. URL https://www.bis.org/publ/bcbs238.pdf.

Bernanke, B. (2007). The financial accelerator and the credit channel. Speech 296, Board of Governors of the Federal Reserve System (U.S.). URL https://www.federalreserve.gov/newsevents/speech/bernanke20070615a.htm.

Blundell-Wignall, A., and Roulet, C. (2013). Business models of banks, leverage and the distance-to-default. $O E C D$ Journal: Financial Market Trends, 2012(2): 7-34. URL https://www.oecd.org/finance/BanksBusinessModels.pdf.

Botos, K. (2016). Money Creation in the Modern Economy. Public Finance Quarterly, 61(4): 442-457. URL https://www.asz.hu/storage/files/files/public-finance-quarterly-articles/2016/botos_2016_4_a.pdf.

Bridges, J., Gregory, D., Nielsen, M., Pezzini, S., Radia, A., and Spaltro, M. (2014). The impact of capital requirements on bank lending. Working Paper 486, Bank of England. URL https://dx.doi.org/10.2139/ssrn.2388773.

Caiani, A., Godin, A., Caverzasi, E., Gallegati, M., Kinsella, S., and Stiglitz, J. E. (2016). Agent based-stock flow consistent macroeconomics: Towards a benchmark model. Journal of Economic Dynamics and Control, 69: 375-408. URL https://doi.org/10.1016/j.jedc.2016.06.001.

Carpenter, S., and Demiralp, S. (2012). Money, reserves, and the transmission of monetary policy: Does the money multiplier exist? Journal of Macroeconomics, 34(1): 59-75. URL https://doi.org/10.1016/j.jmacro.2011.09.009.

Chami, R., and Cosimano, T. F. (2010). Monetary policy with a touch of Basel. Journal of Economics and Business, 62(3): 161-175. URL https://doi.org/10.1016/j.jeconbus.2009.12.001.

Dermine, J. (2013). Bank regulations after the global financial crisis: Good intentions and unintended evil. European Financial Management, 19(4): 658-674. URL http://onlinelibrary.wiley.com/doi/10.1111/j.1468-036X.2013.12017. x/abstract.

Disyatat, P. (2011). The bank lending channel revisited. Journal of Money, Credit and Banking, 43(4): 711-734. URL https://doi.org/10.1111/j.1538-4616.2011.00394.x.

Dombret, A. (2013). Total impact - how regulation and crisis management will change the world's financial landscape. Speech, Deutsche Bundesbank, Frankfurt Finance Summit. URL http://www.bis.org/review/r130320c.pdf.

Farag, M., Harland, D., and Nixon, D. (2013). Bank capital and liquidity. Bank of England Quarterly Bulletin, (Q3). URL https://papers.ssrn.com/sol3/papers.cfm?abstract_id=2327437.

Francis, W., and Osborne, M. (2009). Bank regulation, capital and credit supply: measuring the impact of prudential standards. Occasional Paper 36, UK Financial Services Authority. URL http://www.fsa.gov.uk/pubs/occpapers/op36. pdf.

Francis, W. B., and Osborne, M. (2012). Capital requirements and bank behavior in the UK: are there lessons for international capital standards? Journal of Banking \& Finance, 36(3): 803-816. URL https://doi.org/10.1016/j. jbankfin.2011.09.011.

Fullwiler, S. T. (2012). An endogenous money perspective on the post-crisis monetary policy debate. Review of Keynesian Economics, 1(2): 171-194. URL https://doi.org/10.4337/roke.2013.02.02. 
Furfine, C. (2001). Bank portfolio allocation: The impact of capital requirements, regulatory monitoring, and economic conditions. Journal of Financial Services Research, 20(1): 33-56. URL https://doi.org/10.1023/A:1011147609099.

Gambacorta, L., and Marques-Ibanez, D. (2011). The bank lending channel: lessons from the crisis. Economic Policy, 26(66): 135-182. URL https://www.researchgate.net/publication/227358570_The_Bank_Lending_Channel_ Lessons_from_the_Crisis.

Gambacorta, L., and Mistrulli, P. E. (2004). Does bank capital affect lending behavior? Journal of Financial Intermediation, 13(4): 436-457. URL https://doi.org/10.1016/j.jfi.2004.06.001.

Goodhart, C. A. E. (2006). The ECB and the conduct of monetary policy: Goodhart's law and lessons from the euro area. JCMS: Journal of Common Market Studies, 44(4): 757-778. URL https://doi.org/10.1111/j.1468-5965.2006.00661.x.

Goodhart, C. A. E. (2010). Money, credit and bank behaviour: need for a new approach. National Institute Economic Review, 214(1): F73-F82. URL http://journals.sagepub.com/doi/pdf/10.1177/0027950110389774.

Goodhart, C. A. E. (2013). Goodhart's Law. Le Libellio, 9: 29-33. URL http://lelibellio.com/wp-content/uploads/2013/ 02/Pages-29-\%C3\%A0-33-Goodhart-Ch.-2013-dossier-Goodharts-Law-Libellio-vol.-9-n\%C2\%B0-4.pdf.

Goodhart, C. A. E. (2015). Why monetary policy has been comparatively ineffective? The Manchester School, 83(S1): 20-29. URL https://doi.org/10.1111/manc.12094.

Haldane, A. (2015). Multi-polar regulation. International Journal of Central Banking, 11(3): 385-401. URL http://www.ijcb.org/journal/ijcb15q3a9.htm.

Honda, Y. (2004). Bank capital regulations and the transmission mechanism. Journal of Policy Modeling, 26(6): 675 688. URL https://doi.org/10.1016/j.jpolmod.2004.01.006.

Horváth, R., Seidler, J., and Weill, L. (2014). Bank capital and liquidity creation: Granger-causality evidence. Journal of Financial Services Research, 45(3): 341-361. URL https://www.springerprofessional.de/ bank-capital-and-liquidity-creation-granger-causality-evidence/10836292.

Jakab, Z., and Kumhof, M. (2015). Banks are not intermediaries of loanable funds-and why this matters. Working Paper 529, Bank of England. URL https://EconPapers.repec.org/RePEc:boe:boeewp:0529.

Jiménez, G., and Ongena, S. (2012). Credit supply and monetary policy: identifying the bank balance-sheet channel with loan applications. The American Economic Review, 102(5): 2301-2326. URL https://www.aeaweb.org/articles? id=10.1257/aer.102.5.2301.

Keen, S. (2011). Debunking Economics-Revised and Expanded Edition: The Naked Emperor Dethroned? Zed Books.

Kishan, R. P., and Opiela, T. P. (2000). Bank size, bank capital, and the bank lending channel. Journal of Money, Credit and Banking, 32(1): 121-141. URL http://www.jstor.org/stable/2601095.

Kishan, R. P., and Opiela, T. P. (2006). Bank capital and loan asymmetry in the transmission of monetary policy. Journal of Banking \& Finance, 30(1): 259-285. URL https://doi.org/10.1016/j.jbankfin.2005.05.002.

Komáromi, A. (2007). The effect of the monetary base on money supply-Does the quantity of central bank money carry any information? MNB Bulletin (discontinued), 2(1): 31-37. URL http://www.mnb.hu/letoltes/ bulletin-2007june-komaromi.pdf.

Krug, S., Lengnick, M., and Wohltmann, H.-W. (2015). The impact of Basel III on financial (in) stability: an agent-based credit network approach. Quantitative Finance, 15(12): 1917-1932. URL https://doi.org/10.1080/14697688.2014. 999701.

Li, B., Xiong, W., Chen, L., and Wang, Y. (2017). The impact of the liquidity coverage ratio on money creation: A stock-flow based dynamic approach. Economic Modelling, 67: 193-202. URL https://doi.org/10.1016/j.econmod. 2016.12.016. 
Loutskina, E., and Strahan, P. E. (2009). Securitization and the declining impact of bank finance on loan supply: evidence from mortgage originations. The Journal of Finance, 64(2): 861-889. URL https://doi.org/10.1111/j. 1540-6261.2009.01451.x.

Martin, A., McAndrews, J., and Skeie, D. (2016). Bank lending in times of large bank reserves. International Journal of Central Banking, 12(4). URL http://www.ijcb.org/journal/ijcb16q4a5.htm.

Martynova, N. (2015). Effect of bank capital requirements on economic growth: a survey. Working Paper 467, De Nederlandsche Bank. URL https://econpapers.repec.org/paper/dnbdnbwpp/467.htm.

McLeay, M., Radia, A., and Thomas, R. (2014). Money creation in the modern economy. Quarterly Bulletin Q1, Bank of England. URL http://www.bankofengland.co.uk/publications/Documents/quarterlybulletin/2014/ qb14q1prereleasemoneycreation.pdf.

Mésonnier, J.-S., and Monks, A. (2014). Did the EBA capital exercise cause a credit crunch in the euro area? Working Paper 491, Bank of England. URL https://papers.ssrn.com/sol3/papers.cfm?abstract_id=2451019.

Miles, D., Yang, J., and Marcheggiano, G. (2013). Optimal bank capital. The Economic Journal, 123(567): 1-37. URL https://doi.org/10.1111/j.1468-0297.2012.02521.x.

Moore, B. J. (1988). Horizontalists and verticalists: the macroeconomics of credit money. Cambridge University Press.

Nachane, D. M., Ghosh, S., and Ray, P. (2006). Basel II and Bank Lending Behaviour: some Likely Implications for Monetary Policy. Economic and Political Weekly, 41(11): 1053-1058. URL https://www.jstor.org/stable/4417969? seq=1\#page_scan_tab_contents.

Noss, J., and Toffano, P. (2014). Estimating the impact of changes in bank capital requirements during a credit boom. Working Paper 494, Bank of England. URL https://www.bankofengland.co.uk/-/media/boe/files/working-paper/2014/ estimating-the-impact-of-changes-in-aggregate-bank-capital-requirements-during-an-upswing.pdf?la=en\&hash= FF88930DB4AA370D90F1AC9EFC1501CE4A357E10.

Palley, T. I. (1994). Competing views of the money supply process: theory and evidence. Metroeconomica, 45(1): 67-88. URL https://doi.org/10.1111/j.1467-999X.1994.tb00013.x.

Panagopoulos, Y. (2010). Basel II and the money supply process: some empirical evidence from the Greek banking system. Applied Economics Letters, 17(10): 973-976. URL https://doi.org/10.1080/13504850802599482.

Peek, J., and Rosengren, E. (1995a). Bank regulation and the credit crunch. Journal of Banking \& Finance, 19(3): 679-692. URL https://doi.org/10.1016/0378-4266(94)00148-V.

Peek, J., and Rosengren, E. (1995b). The capital crunch: neither a borrower nor a lender be. Journal of Money, Credit and Banking, 27(3): 625-638. URL http://www.jstor.org/stable/2077739.

Peek, J., and Rosengren, E. S. (1997). The international transition of financial shocks: the case of Japan. The American Economic Review, 87(4): 495-505. URL http://www.jstor.org/stable/2951360.

Peek, J., and Rosengren, E. S. (2010). The role of banks in the transmission of monetary policy. In J. O. S. W. Allen N. Berger, Philip Molyneux (Ed.), The Oxford Handbook of Banking. Oxford: Oxford University Press. URL http:// www.oxfordhandbooks.com/view/10.1093/oxfordhb/9780199640935.001.0001/oxfordhb-9780199640935-e-010.

Puri, M., Rocholl, J., and Steffen, S. (2011). Global retail lending in the aftermath of the US financial crisis: Distinguishing between supply and demand effects. Journal of Financial Economics, 100(3): 556-578. URL https://doi.org/10.1016/j.jfineco.2010.12.001.

Quinaz, P. D., and Curto, J. D. (2016). Prudential regulation in an artificial banking system. Economics, 10(31): 1. URL http://www.economics-ejournal.org/economics/discussionpapers/2016-27. 
Ryan-Collins, J., Greenham, T., Werner, R., and Jackson, A. (2012). Where does money come from. A guide to the UK monetary and banking system, 2.

Simon, G. (2011). Central Bank Balances and Reserve Requirements. Working Paper No. 11/36, International Monetary Fund. URL https://www.imf.org/en/Publications/WP/Issues/2016/12/31/ Central-Bank-Balances-and-Reserve-Requirements-24648.

Slovik, P., and Cournède, B. (2011). Macroeconomic Impact of Basel III. Working Paper 844, OECD Economic Department. URL https://ssrn.com/abstract=2650033.

Van den Heuvel, S. J. (2002). Does bank capital matter for monetary transmission? Economic Policy Review, 8(1): 259-265. URL https://papers.ssrn.com/sol3/papers.cfm?abstract_id=831946.

Van den Heuvel, S. J. (2006). The bank capital channel of monetary policy. 2006 meeting papers, Society for Economic Dynamics. URL https://ideas.repec.org/p/red/sed006/512.html.

VanHoose, D. (2007). Theories of bank behavior under capital regulation. Journal of Banking \& Finance, 31(12): 3680-3697. URL https://doi.org/10.1016/j.jbankfin.2007.01.015.

Werner, R. (2010). Towards stable and competitive banking in the UK-evidence for the Independent Commission on Banking (ICB). CBFSD Policy Discussion Paper 3/1-10. URL https://eprints.soton.ac.uk/342277/1/Werner_Soton_ Towards_Stable_Banking_201011.pdf.

Werner, R. A. (2014). Can banks individually create money out of nothing?The theories and the empirical evidence. International Review of Financial Analysis, 36: 1-19. URL https://doi.org/10.1016/j.irfa.2014.07.015.

Xiong, W., Li, B., Wang, Y., and Stanley, H. E. (2018). The versatility of money multiplier under Basel III regulations. Social Science Electronic Publishing. URL https://ssrn.com/abstract=3192147.

Yan, M., Hall, M. J., and Turner, P. (2012). A cost-benefit analysis of Basel III: Some evidence from the UK. International Review of Financial Analysis, 25: 73-82. URL https://doi.org/10.1016/j.irfa.2012.06.009.

\section{Appendix}

\section{A Derivation of Equation (19)}

Combining Equations (9) and (12), we have

$$
\begin{gathered}
L(2)-L(1)=L F(1)-R P(1)=L F(1), \\
L(3)-L(2)=L F(2)-R P(2)=L F(2)-\frac{1}{\theta} L F(1), \\
L(4)-L(3)=L F(3)-R P(3)=L F(3)-\frac{1}{\theta}[L F(2)+L F(1)], \\
\vdots \\
L(\theta+1)-L(\theta)=L F(\theta)-R P(\theta)=L F(\theta)-\frac{1}{\theta}[L F(\theta-1)+L F(\theta-2)+\ldots+L F(1)], \\
L(\theta+2)-L(\theta+1)=L F(\theta+1)-R P(\theta+1)=L F(\theta+1)-\frac{1}{\theta}[L F(\theta)+L F(\theta-1)+\ldots+L F(1)], \\
L(\theta+3)-L(\theta+2)=L F(\theta+2)-R P(\theta+2)=L F(\theta+2)-\frac{1}{\theta}[L F(\theta+1)+L F(\theta)+\ldots+L F(2)], \\
\vdots \\
L(t-1)-L(t-2)=L F(t-2)-R P(t-2)=L F(t-2)-\frac{1}{\theta}[L F(t-3)+L F(t-4)+\ldots+L F(t-\theta-2)], \\
L(t)-L(t-1)=L F(t-1)-R P(t-1)=L F(t-1)-\frac{1}{\theta}[L F(t-2)+L F(t-3)+\ldots+L F(t-\theta-1)] .
\end{gathered}
$$


Summing these equations up, we have

$$
L(t)-L(1)=\left\{\begin{array}{l}
L(t-1)+\frac{\theta-1}{\theta} L F(t-2)+\ldots+\frac{1}{\theta} L F(t-1), 2 \leq t \leq \theta+1 ; \\
L(t-1)+\frac{\theta-1}{\theta} L F(t-2)+\ldots+\frac{1}{\theta} L F(t-\theta), t \geq \theta+1 .
\end{array}\right.
$$

With $L(1)=0$, Equation (62) can be rewritten as

$$
L(t)=\left\{\begin{array}{l}
\sum_{t^{\prime}=1}^{t-1} \frac{\theta-t^{\prime}+1}{\theta} L F\left(t-t^{\prime}\right), 2 \leq t \leq \theta+1 ; \\
\sum_{t^{\prime}=1}^{\theta} \frac{\theta-t^{\prime}+1}{\theta} L F\left(t-t^{\prime}\right), t \geq \theta+1 .
\end{array}\right.
$$

Combining Equation (63) with Equation (15) and (17), we have : $\forall t \geq t^{*} \geq \theta+1$,

$$
L(t)=L^{*}=\sum_{t^{\prime}=1}^{\theta} \frac{\theta-t^{\prime}+1}{\theta} L F(t)=\frac{1+\theta}{2} L F^{*}=\frac{1+\theta}{2} R P^{*} .
$$

In other words,

$$
L F(t)=R P(t)=L F^{*}=\frac{2}{1+\theta} L^{*}, t \geq t^{*} .
$$

B Rewriting the conditions of $I F^{*} \geq 0.75 O F^{*}$ and $I F^{*}<0.75 O F^{*}$ as a function of $\mu, \theta, g$ and $c$

For the first condition, $I F \geq 0.75 O F$, we should have

$$
\begin{aligned}
\frac{L^{*}}{1+\theta} & \geq 0.75 \mu D^{*} \\
\Rightarrow \frac{D^{*}-(R+G-C)}{1+\theta} & \geq 0.75 \mu D^{*} \\
\Rightarrow[1-0.75 \mu(1+\theta)] D^{*} & \geq R+G-C .
\end{aligned}
$$

For Equation (66) to hold, we should always have $1-0.75 \mu(1+\theta)>0$, i.e. $\mu<\frac{4}{3(1+\theta)}$. Substituting the corresponding expression for the equilibrium deposits under this condition, $D^{*}=\frac{4(R+G)}{\mu r_{L C R}}$, into Equation (66), we have

$$
\begin{gathered}
{[1-0.75 \mu(1+\theta)] \frac{4(R+G)}{\mu r_{L C R}} \geq R+G-C} \\
\Rightarrow \mu \leq \frac{4(1+g)}{\left(3 \theta+3+r_{L C R}\right)(1+g)-c r_{L C R}}
\end{gathered}
$$

where $\frac{4(1+g)}{\left(3 \theta+3+r_{L C R}\right)(1+g)-c r_{L C R}}<\frac{4}{3(1+\theta)}$ always holds because

$$
\begin{aligned}
& \frac{4(1+g)}{\left(3 \theta+3+r_{L C R}\right)(1+g)-c r_{L C R}}-\frac{4}{3(1+\theta)} \\
& =\frac{4 r_{L C R}(c-1-g)}{3(1+\theta)\left[\left(3 \theta+3+r_{L C R}\right)(1+g)-c r_{L C R}\right]}<0 .
\end{aligned}
$$

Therefore, the first condition of $I F \geq 0.75 O F$ is equivalent to $\mu \leq \frac{4(1+g)}{\left(3 \theta+3+r_{L C R}\right)(1+g)-c r_{L C R}}$. Correspondingly, the second condition of $I F<0.75 O F$ can be replaced by $\mu>\frac{4(1+g)}{\left(3 \theta+3+r_{L C R}\right)(1+g)-c r_{L C R}}$.

C The more generalized expressions for the money supply and money multiplier under the LCR regulation after relaxing the assumption of $50 \%$ inflow rate for bank loans

This assumption of 50\% inflow rate for bank loans used in Equation (25) can be relaxed by the following equation:

$$
I F(t)=\omega * R P(t),
$$


where $\omega$ is denoted as the inflow rate of the repayments for outstanding bank loans. $\omega$ is generally higher when the counterparty to which bank loans are made has higher credit ratings and can successfully fulfil its debt obligations in stressed condition. Following similar procedures elaborated in Section 4.1, we can obtain the corresponding expressions for the money supply $M$ and money multiplier $m$ when the bank is constrained by the LCR regulation, i.e.

$$
\begin{aligned}
& M_{L C R}=\left\{\begin{array}{l}
\frac{4(R+G)}{\mu r_{L C R}}, \mu \leq \frac{8 \omega(1+g)}{\left(3 \theta+3+2 \omega r_{L C R}\right)(1+g)-2 \omega c r_{L C R}} ; \\
\frac{(R+G)\left(1+\theta-2 \omega r_{L C R}\right)+2 \omega r_{L C R} C}{r_{L C R}[\mu(1+\theta)-2 \omega]}, \mu>\frac{8 \omega(1+g)}{\left(3 \theta+3+2 \omega r_{L C R}\right)(1+g)-2 \omega c r_{L C R}} .
\end{array}\right. \\
& m_{L C R}=\left\{\begin{array}{l}
\frac{4(1+g)}{\mu r_{L C R}, \mu \leq \frac{8 \omega(1+g)}{\left(3 \theta+3+2 \omega r_{L C R}\right)(1+g)-2 \omega c r_{L C R}} ;} \\
\frac{(1+g)\left(1+\theta-2 \omega r_{L C R}\right)+2 \omega c r_{L C R}}{r_{L C R}[\mu(1+\theta)-2 \omega]}, \mu>\frac{8 \omega(1+g)}{\left(3 \theta+3+2 \omega r_{L C R}\right)(1+g)-2 \omega c r_{L C R}} .
\end{array}\right.
\end{aligned}
$$

It is straightforward to know that if $\mu>\frac{8 \omega(1+g)}{\left(3 \theta+3+2 \omega r_{L C R}\right)(1+g)-2 \omega c r_{L C R}}($ i.e. $I F<0.75 * O F)$, then $\frac{\partial M}{\partial \omega}>0, \frac{\partial m}{\partial \omega}>0$. In other words, if bank loans are made to borrowers with higher credit ratings who can provide larger cash inflow for the bank during stressed condition, the banking system has greater capacity to create money when constrained by the LCR regulation.

\section{Calibration of model parameter based on historical data for the U.S. banking system}

\begin{tabular}{|c|c|c|c|c|c|}
\hline Year & $R$ (\$ billion) & $C(\$$ billion $)$ & CET1(\$ billion) & $C / R$ & $C E T 1 / R$ \\
\hline 1992 & 298 & 263 & 246 & 0.88 & 0.83 \\
\hline 1993 & 273 & 297 & 277 & 1.09 & 1.01 \\
\hline 1994 & 304 & 312 & 287 & 1.03 & 0.94 \\
\hline 1995 & 307 & 350 & 318 & 1.14 & 1.04 \\
\hline 1996 & 336 & 376 & 329 & 1.12 & 0.98 \\
\hline 1997 & 355 & 418 & 354 & 1.18 & 1.00 \\
\hline 1998 & 357 & 462 & 379 & 1.29 & 1.06 \\
\hline 1999 & 366 & 480 & 378 & 1.31 & 1.03 \\
\hline 2000 & 370 & 530 & 423 & 1.43 & 1.14 \\
\hline 2001 & 390 & 594 & 469 & 1.52 & 1.20 \\
\hline 2002 & 384 & 647 & 517 & 1.68 & 1.35 \\
\hline 2003 & 387 & 692 & 527 & 1.79 & 1.36 \\
\hline 2004 & 388 & 850 & 568 & 2.19 & 1.46 \\
\hline 2005 & 400 & 912 & 604 & 2.28 & 1.51 \\
\hline 2006 & 433 & 1030 & 666 & 2.38 & 1.54 \\
\hline 2007 & 482 & 1143 & 715 & 2.37 & 1.48 \\
\hline 2008 & 1042 & 1154 & 755 & 1.11 & 0.72 \\
\hline 2009 & 976 & 1332 & 918 & 1.36 & 0.94 \\
\hline Mean & 436.00 & 657.89 & 485.00 & 1.51 & 1.14 \\
\hline Min & 273 & 263 & 246 & 0.88 & 0.72 \\
\hline Max & 1042 & 1332 & 918 & 2.38 & 1.54 \\
\hline \multicolumn{6}{|c|}{$\begin{array}{l}\text { Notes: This table provides the historical data of reserves and capital for the U.S. banking system from } \\
1992 \text { to } 2009 \text { used for the calibration of the model parameter } c \text {, the capital-to-reserve ratio. Data are } \\
\text { obtained by author based on the work of Slovik and Cournède }(2011) \text {. Based on the ratio of bank capital } \\
\text { to reserves }(C / R) \text { and the ratio of core-Tier } 1 \text { capital to reserves }(C E T 1 / R) \text {, we determine that } c=0.8 \\
\text { corresponds to relatively low capital positions and } c=2 \text { indicates relatively high capital positions. }\end{array}$} \\
\hline
\end{tabular}

Table 3: Historical data of capital and reserves for the U.S. banking system 


\section{Economics}

Please note:

You are most sincerely encouraged to participate in the open assessment of this article. You can do so by either recommending the article or by posting your comments.

\section{Please go to:}

http://dx.doi.org/10.5018/economics-ejournal.ja.2018-41

The Editor 